\title{
Linking geospatial information and effects of land management to edaphic properties
}

\author{
A. Fortuna, J.L. Steiner, D.N. Moriasi, B.K. Northup, and P.J. Starks
}

\begin{abstract}
This study combines geospatial data and a classification scheme that uses landform elements to derive landform complexes that codify the collection of soils data at variable scale within a single field site. Our experiment was initiated in 2018 on three, 1.6 ha self-contained watersheds representing a southern tall grass prairie (STGP), a system of continuous winter wheat (Triticum aestivum) tilled via offset disking and chisel plow (WWCT), and a minimally disturbed winter wheat system that was periodically planted to a warm season forage, typically sorghum-sudangrass (Sorghum bicolor L.) (WWMT) from 1978 to 2018. A class I soil survey was conducted in 2018 by grid sampling the landscape of all watershed systems at the site. The survey indicated four distinct catena were present across all watersheds, which enabled us to utilize a split block design. This statistical approach allowed for testing of interactions among management practices, landscape position, and soil depth to obtain means and standard errors for different edaphic properties. Using a hydraulic probe, 144 random soil cores were collected to a $30 \mathrm{~cm}$ depth at each of the four $4.6 \mathrm{~m}$ by $3.8 \mathrm{~m}$ replicated blocks per landscape position (tread, riser, and toe) within the three watersheds. Cores were further divided into three depths ( 0 to 5,5 to 15 , and 15 to $30 \mathrm{~cm}$ ). Baseline analyses included Mehlich-3, soil sulfate $\left(\mathrm{SO}_{4}\right)$ and DTPA-sorbitol extractions, soil texture, bulk density, $\mathrm{pH}$, total soil organic carbon (TSOC) and total soil nitrogen (TSN), particulate organic matter (POM), and nonhydrolysable $\mathrm{C}(\mathrm{RCAH})$, the resistant fraction of soil organic $\mathrm{C}$. The majority of edaphic properties associated with soil classification varied with landscape position and depth. These included clay content, base saturation (calcium [Ca], magnesium $[\mathrm{Mg}]$, and potassium $[\mathrm{K}]$ ), $\mathrm{pH}$, and sulfur in the form of sulfate $\left(\mathrm{SO}_{4}-\mathrm{S}\right)$ and phosphorus $(\mathrm{P})$. Carbon and $\mathrm{N}$ fractions varied with land use, conservation practices, and/or depth. The establishment of replicate sampling stations that account for and limit the spatial variability of edaphic properties within defined landform complexes enables researchers to more accurately quantify the effects of conservation practices and land management.
\end{abstract}

Key words: carbon—conservation practices—edaphic properties-landform complexesnitrogen-particulate organic matter

\begin{abstract}
The creation of replicate sampling stations that represent landform complexes within uniform zones of management can aid researchers in addressing variations in scale and the inherent spatial variability associated with field research that limits comparisons among management practices. Both crop and animal agriculture in the Southern Great Plains are subject to high degrees of variability in both climate and natural resources (Steiner et al. 2018). Management practices that conserve soil and
\end{abstract}

Received September 18, 2020 ; Revised May 11, 2021; Accepted May 11, 2021; Published online August 20, 2021.
Resources Erosion [WRE] site) located at the USDA Agricultural Research Service (ARS) Grazinglands Research Laboratory in El Reno, Oklahoma, to address "agricultural sustainability, climate change, ecosystem services, and conservation of natural resources at the watershed or landscape scale"-a primary objective of the USDA ARS Conservation Effects Assessment Project (CEAP) (Mausbach and Dedrick 2004; Duriancik et al. 2008) and the Long-Term Agro-Ecosystem Research (LTAR) network (Spiegal et al. 2018; Kleinman et al. 2019; Nelson et al. 2020).

Globally and regionally, retention and distribution of organic material and nutrients in agroecosystems vary due to landscape-scale management and terrain attributes (elevation, slope, aspect, and texture), and anthropogenic management (Liu et al. 2006; Viaud et al. 2010; Zhang et al. 2011; Blanchet et al. 2017). These observations indicate that topographic and soil controls strongly influence nutrient distributions, losses, and uptake patterns within fields, affecting soil and water quality at microsite and landscape scales. Adoption of precision agriculture and grid sampling techniques to assess and adjust for the effects of terrain attributes on yield became feasible in the 1980s and 1990s, when computational capabilities of computers increased and global positioning system (GPS) applications became feasible (Stafford 2000). Once these tools were more widely available, proponents of soil and water conservation recommended their use to manage natural resources, and to adapt to climatic variation and change (Delgado et al. 2011).

Conservation management and terrain attributes partially determine mineralization-immobilization and turnover of nutrients and their potential loss. Additionally, mixtures

water can aid in mitigation of and adaptation to climate variability and change (Delgado et al. 2011; Lal et al. 2011). The National Institute of Food and Agriculture has defined climate change as "a trend of significant fluctuations in major weather patterns and conditions brought about by increased greenhouse gases. The trend has seen significant variations in temperature, rain, wind, and other factors over a period of years" (USDA NIFA 2020). Research is being conducted on eight 1.4 ha sized watersheds (the Water

Ann-Marie Fortuna is a research soil scientist in the Grazinglands Research Laboratory, USDA Agricultural Research Service (ARS), El Reno, Oklahoma. Jean L. Steiner is a professor emeritus, Grazinglands Research Laboratory, USDA ARS, El Reno, Oklahoma, and adjunct professor, Department of Agronomy, Kansas State University, Manhattan, Kansas. Daniel N. Moriasi is a research hydrologist in the Grazinglands Research Laboratory, USDA ARS, El Reno, Oklahoma. Brian K. Northup is a research ecologist in the Grazinglands Research Laboratory, USDA ARS, El Reno, Oklahoma. Patrick J. Starks is the acting director of the Grazinglands Research Laboratory, USDA ARS, El Reno, Oklahoma. 
of residues in polycultures, such as the southern tall grass prairies (STGP) included in this experiment (a USDA Natural Resources Conservation Service [NRCS] recommended conservation practice standard, code 340), may act as reserves for excess nutrients preventing losses (Matson et al. 1997) and aiding in the timing and release of plant available $\mathrm{N}$ with crop uptake (Lawson et al. 2013). However, reduced tillage and yearround (living) plant cover stratifies nutrients and increases field heterogeneity, reducing our ability to discern differences in land management (Bauer et al. 2002).

Nutrient concentrations and terrain attributes of soils are integral components of soil quality and health (used interchangeably in the current discussion). Soil quality is evaluated using inherent and dynamic soil properties that serve as indicators of soil function. These include sustaining biological diversity, activity, and productivity regulating water and solute flow; filtering, buffering, degrading organic and inorganic materials; storing and cycling nutrients and carbon (C); and providing physical stability and support (Larson and Pierce 1991). Inherent or use-invariant, soil properties such as aspect, slope, soil texture, type of clay, depth to bedrock, and drainage class change little or not at all with management forming over time (Doran et al. 1996). Management and natural disturbances that typically occur among growing seasons and decades affect dynamic soil properties. Indicators of soil quality are divided into physical, chemical, and biological categories relating to the soil function affected. Each category represents both inherent and dynamic indicators (Doran et al. 1996). Implementation of soil and water conservation practices in cropping and grassland systems were shown to reduce erosion while sustaining soil quality through the retention of residues and soil organic matter (Sanderson et al. 2013).

High-intensity soil survey methods are used when "detailed and very precise knowledge of soils and their variability' are required (USDA NRCS 2019). Despite the effectiveness of such surveys, greater detail with respect to soil properties is required for farm and range management. During the last several decades geostatistics and precision agriculture have become tools used to assess and interpret data related to soil quality in the context of spatial variability and conser- vation practices (Allen et al. 2010; Killham and Staddon 2002; Lerch et al. 2005).

Seasonal variations in plant available nitrogen $(\mathrm{N})$ and $\mathrm{C}$ turnover can be estimated via measurements of particulate organic matter $\mathrm{C}$ (POMC) and $\mathrm{N}$ that contain significant proportions of plant material (Cambardella and Elliott 1993). Estimates of nonhydrolysable $\mathrm{C}(\mathrm{RACH})$ turnover rates are in the 100 s to 1,000 s of years' timeframe (Paul et al. 2001a). Despite lengthy turnover rates, the amount of $\mathrm{C}$ contained in $\mathrm{RCAH}$ can increase in years or decades with the addition of compost, animal wastes, or other materials containing recalcitrant compounds (Fortuna et al. 2003b). The POM fraction typically contains material with biologically active $\mathrm{C}$ and $\mathrm{N}$ and other materials with intermediate turnover rates (Fortuna et al. 2018). The pool of resistant $\mathrm{C}$, defined in this paper as $\mathrm{RCAH}$, can serve as a stable measure or marker that remains constant over time. In contrast, soil organic C (SOC) contains both biologically active and inactive components that temporarily mask the effects of conservation management on $\mathrm{C}$ storage and cycling (Stockmann et al. 2013). Particulate organic matter and RCAH provide information with respect to the short- and long-term effects of land use and conservation management on soil $\mathrm{C}$ and $\mathrm{N}$ processes.

Our research focuses on identifying and testing diversified, adaptive systems of crop and livestock production that reduce disturbance and improve soil and water quality while enhancing productivity. Previous research on the WRE determined that landscape position and applied management had significant effects on the concentration and distribution of soil organic matter (SOM) (Northup and Daniel 2010). Other researchers in the Plains region have also determined that terrain and land management affect the distribution and cycling of nutrients. Specifically, toe slopes had higher total soil C, $\mathrm{N}$, phosphorus $(\mathrm{P})$, and mineralization rates across a range of landscapes in Colorado (Burke et al. 1995). The same study found that treatments involving no-till or perennial grasses immobilized $\mathrm{N}$ and resulted in higher rates of $\mathrm{C}$ mineralization than tilled treatments on sites and landscape positions with high productivity and organic matter concentrations after five years of management.

An objective of our study is to combine geospatial data and a landform element classification scheme to derive landform complexes that codify the collection of soil and water data at variable scale within a single field experiment. An additional objective is to establish replicate sampling stations within defined landform complexes to explain and limit spatial variability that confounds researchers' interpretation of the effects of soil conservation practices and land use on edaphic properties that also serve as soil quality measurements. Indicators in this experiment include terrain attributes (elevation, slope, aspect, and texture) and measurements obtained from routine soil testing analysis. We also contrast the utilization of current soil quality measures, total soil organic C (TSOC) and total soil N (TSN), with alternate measures of $\mathrm{C}$ fractions used to assess conservation management and land use. Our long-term goal is to derive a set of flexible real-time guidelines that growers can use in on site management of a field or portion of a field, and to determine the optimal time required to improve soil quality in agroecosystems under conservation management practices (reduced tillage, forage-based cover crops, and rotational grazing at low stocking rates).

\section{Materials and Methods}

Site Description. This study was undertaken within the WRE watersheds located on the USDA ARS Grazinglands Research Laboratory, near El Reno, Oklahoma (353' $\left.29^{\prime \prime} \mathrm{N}, 98^{\circ} 1^{\prime} 50^{\prime \prime} \mathrm{W}\right)$. The watersheds were constructed in 1976 and included eight experimental paddocks, with four managed as STGP and four managed as cropland. The site was STGP prior to the WRE initiative, with the larger land unit containing the paddocks grazed by groups of cow/calf pairs. Manmade berms, ridges, and natural boundaries that create self-contained watersheds surround each unit. Each unit is 80 $\mathrm{m}$ in width, $200 \mathrm{~m}$ in length, and encloses $1.6 \mathrm{ha}$. Slopes of the watersheds are oriented east to west and range between $3 \%$ and $4 \%$. The plant community of all units in STGP for the site are dominated by big bluestem (Andropogon gerardii Vitman), indiangrass (Sorghastrum nutans [L.] Nash), and little bluestem (Schizachyrium scoparium [Michx.] Nash), with a mixture of other tall, short, and mid-grass species combined with a range of broadleaf species (forbs). Depending on growing conditions and management, the three dominant species generate $60 \%( \pm 10 \%)$ of total biomass produced by native pad- 
docks. All watersheds maintained in STGP were remnant prairies that were never tilled or planted to agronomic crops.

Three of the eight paired watersheds representing each land use and management were selected for this experiment. Watersheds 2 and 4 were to be converted from grassland to conservation management in the fall of 2018. Therefore, they were not included in the current experiment. Watersheds 1 and 5 were chosen in part because the spatial variability of SOM had been previously mapped by Northup and Daniel (2010) in 2004. The third watershed unit 8 was chosen from the two remaining watersheds maintained as continuously tilled winter wheat (Triticum aestivum). Watershed unit 8 was selected because it contained the least soil variability and more consistent management relative to unit 6 . In the current study, watershed unit 1 is maintained as STGP.Watershed unit 5 (WWMT) is under low-disturbance management using no or minimal tillage and planted to winter wheat since 1976 Watershed 5 was disturbed in 1986 only by means of offset disking twice and harrowing. In years prior to 2000, watershed 5 was also planted to summer forage crops that included forage sorghum (Sorghum bicolor L.) and Sudan grass (Sorghum sudanense) in rotation with winter wheat. Lespedeza (Lespedeza cuneate) was planted as a summer forage in 1999 only. Watershed unit 8 (WWCT) has been managed using a combination of offset disking and chisel plowing and planted to winter wheat since 1976 (figure 1). The above truncated description of management applied to the watersheds was derived from Nelson et al. (2020) and Vogel et al. (2000). A detailed description of all management practices including fertilizer applications is available at https://doi.org/10.15482/ USDA.ADC/1518421. Fertilization of the WWMT treatment (unit 5) was the same as WWCT (unit 8) apart from the equivalent of a $38 \mathrm{~kg} \mathrm{ha}^{-1} \mathrm{~N}$ application to the summer forage crops.

Average annual maximum and minimum air temperature is $22^{\circ} \mathrm{C}$ and $9^{\circ} \mathrm{C}$ with ranges as high as $46^{\circ} \mathrm{C}$ and low as $-26^{\circ} \mathrm{C}$. Average annual precipitation is $838 \mathrm{~mm}$ with highs of $1,372 \mathrm{~mm}$ and lows of $381 \mathrm{~mm}$. The average number of days with precipitation per year is 68 . Average monthly precipitation ranges from 25.4 to $127 \mathrm{~mm}$ and has a bimodal distribution falling primarily in May to June and again in September and October

\section{Figure 1}

The eight Water Resources and Erosion (WRE) watersheds located at the USDA Agricultural Research Service (ARS) Grazinglands Research Lab in El Reno, Oklahoma, United States. This paired watershed experiment has been in continuous management since 1976.

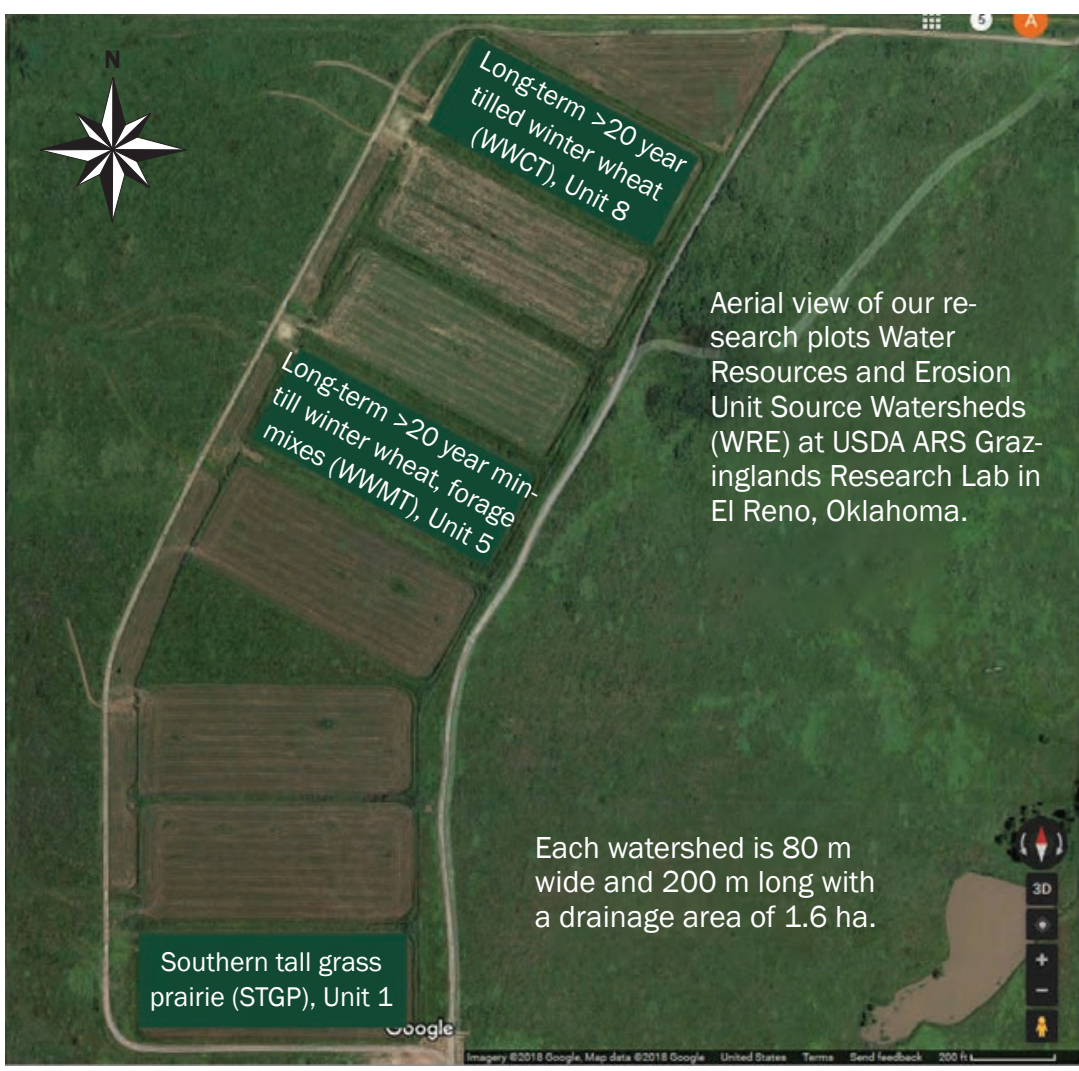

(Mesonet, El Reno, Oklahoma; https:// www.mesonet.org).

Grid and Zone Sampling of Soil. Our sampling scheme was based on a class I soil survey from 2018 conducted in partnership with NRCS. The survey included all eight WRE paired watersheds. Variations in SOM measurements taken by Northup and Daniel (2010) in 2004 from watershed unit 1 in STGP management and watershed unit 5 in low-disturbance management cropped to winter wheat and periodically planted to summer forages were examined prior to implementing a sampling design. This previous research on the WRE confirmed that responses of SOM to long-term management were confounded by terrain attributes within individual paddocks and across paddocks (Northup and Daniel 2010). Their findings indicated that SOM remained constant in $\sim 4.5 \mathrm{~m}$ area patches that varied due to the effects of soil catenas located at the tread, riser, and toe. Additionally, some variability could be removed by excluding the $\sim 15 \mathrm{~m}$ area boarding the berms surrounding each watershed. Watershed treatments on the WRE were grid sampled in 2018 outside of the $15 \mathrm{~m}$ boarder described above at four 4.6 $\mathrm{m}$ by $3.8 \mathrm{~m}$ replicated blocks per landscape position-a sampling density that reflected the spatial variability measured by Northup and Daniel (2010). Baseline samples of soils were taken in 2018 and analyzed for TSOC, TSN, pH, and plant nutrients. Once we determined that baseline measurements varied within the same sampling density, each watershed treatment was divided into replicate sampling stations that represent landform complexes within uniform zones of management.

The majority of soils located within the WRE are silt loams, derived from undifferentiated Dog Creek Shale and Blaine Formations of the El Reno Group (Daniel 2001). For this study, soil samples were obtained from watershed units 1 (STGP), 5 (WWMT), and 8 (WWCT). Each watershed was grid sampled at the tread, riser, and toe slopes to create four replicate sampling zones within each landscape position 
by watershed, capturing the catena effects, slopes, and aspects. Using a hydraulic probe, 144 soil cores were collected from three of the watersheds at tread, riser, and toe slopes. Each watershed by slope contained four, $4.6 \mathrm{~m}$ by $3.8 \mathrm{~m}$ blocks from which four random soil cores 0 to $30 \mathrm{~cm}$ were taken. A Garmin ETrex 10 Outdoor Handheld GPS Navigation Unit-AW16 (Garmin Ltd., Olathe, Kansas) was used to record the locations of the corners of each of the sampling zones at each of the three landscape positions on the three watersheds (Fortuna et al. 2019). Creation of the four replicated blocks within a landscape position (tread, riser, and toe) and watershed unit enabled us to define the landform complexes needed to create uniform zones within managed paddocks that represented the variable characteristics of soils that affect production within and across watersheds. A Giddings (Windsor, Colorado) Probe, Model HDGSRPS, fitted with poly-ethylene terephthalate glycol (PTEG) soil tube liners (inert to chemicals and contaminants) was used to collect soil samples. Each soil core was capped at both ends and immediately frozen at $-18^{\circ} \mathrm{C}$.

The volume of the core was recorded. Whole soil cores were weighed prior to freezing. Weights corrected for gravimetric moisture and core volume were used to calculate bulk density to $30 \mathrm{~cm}$ depth via the core method. Frozen soil cores were cut into three depths ( 0 to 5,5 to 15 , and 15 to $30 \mathrm{~cm}$ ) using a miter saw. The volume of each depth increment was recorded as was the field moist weight. Weights corrected for gravimetric moisture and core volume per depth were used to calculate a bulk density at 0 to 5,5 to 15 , and 15 to $30 \mathrm{~cm}$ depths (Blake and Hartge 1986). Soil samples were thawed, thoroughly mixed, and passed through a 2 $\mathrm{mm}$ sieve. Sieving removed plant residue to allow for further mixing and homogenized soil samples. Each watershed contained four replicate soil samples per landscape position by depth from which edaphic properties were measured.

Soil Analysis. Edaphic indicators chosen for this experiment varied within the same spatial scale of a given watershed management and landscape position. Gravimetric water content was determined for each of the original 144 soil samples (Gee and Bauder 1986). The texture of each soil sample was determined by the soil hydrometer method (Huluka and Miller 2014). Subsamples of each soil were dried to a constant weight at $60^{\circ} \mathrm{C}$ in a Fisherbrand Isotemp heating and drying oven (Fisher Scientific, Waltham, Massachusetts). After oven drying, each of the 144 soil samples were further subsampled for POM and nonhydrolysable C, i.e., residual $\mathrm{C}$ by acid hydrolysis ( $\mathrm{RCAH}$ ) (Paul et al. 2001b). Several steps are required to extract POM, defined as the organic C and $\mathrm{N}$ associated with sand-sized soil constituents remaining on a $53 \mu \mathrm{m}$ sieve after soil is passed through a $2 \mathrm{~mm}$ sieve and dispersed with hexametaphosphate (Gregorich et al. 2008). Rinsed POM materials were transferred into aluminum weighing boats and oven dried at $60^{\circ} \mathrm{C}$ for 24 hours. Dried POM samples were ground with a mortar and pestle to pass a $250 \mathrm{~mm}$ sieve.

The resistant $\mathrm{C}$ fraction defined as the $\mathrm{RCAH}$ fraction constituting $~ 50 \%$ to $70 \%$ of TSOC is not biologically active but contributes to the capacity of soil to hold water, soil structure, aggregation, and other physical properties of soil (Paul et al. 2001b). RCAH in soil was isolated using oven-dried subsamples weighing $1 \mathrm{~g}$. Each $1 \mathrm{~g}$ soil sample was added to a $50 \mathrm{~mL}$ digestion tube in which 25 $\mathrm{mL}$ of $6 \mathrm{~mol} \mathrm{~L}^{-1} \mathrm{HCl}$ was added. Tubes were then vortexed briefly for 30 seconds. Tubes were added to a DigiPREP HT Digestion block (SCP SCIENCE, Champlain, New York), a manifold was placed on top of the tubes, and the block was maintained at $115^{\circ} \mathrm{C}$ for 18 hours. Thereafter, the tubes were cooled to room temperature and centrifuged for 5 minutes. The majority of the acid was decanted off without loss of the remaining soil material, and $50 \mathrm{~mL}$ of deionized water $\left(\mathrm{diH}_{2} \mathrm{O}\right)$ was added to each tube. Each digestion tube was then vortexed, allowed to settle for 24 hours, centrifuged, and the liquid decanted. This process was repeated three times. Remaining soils in samples were then transferred to aluminum weigh tins and oven dried at $60^{\circ} \mathrm{C}$ for 24 hours, cooled, and weighed immediately.

Oven-dried whole soil, POM, and RCAH were weighed and ground using a mortar and pestle $(<0.25 \mathrm{~mm})$. Half-gram samples of oven-dried soil, POM, and RCAH were then weighed for TSN, SOC, POMN, POMC, and RCAH carbon analysis on a 928 Series LECO C/N Analyzer (Leco Corporation, St. Joseph, Michigan) via dry combustion.

Additional baseline measurements related to soil fertility were analyzed at The Soil, Water, and Forage Analytical Laboratory located at Oklahoma State University in Stillwater, Oklahoma. Analyses included buffered and unbuffered pH (Sims 1996; Sikora 2006), Mehlich-3 extraction (Mehlich 1984), DTPA-sorbitol extraction of micronutrients (Gavlak et al. 2003), and soil sulfate $\left(\mathrm{SO}_{4}-\mathrm{S}\right)$ extraction with $0.008 \mathrm{M}$ calcium phosphate $\left[\mathrm{Ca}_{3}\left(\mathrm{PO}_{4}\right)_{2}\right]$. Mehlich 3 extracted $\mathrm{P}$, calcium $(\mathrm{Ca})$, magnesium $(\mathrm{Mg})$, and potassium $(\mathrm{K})$ and $\mathrm{SO}_{4}-\mathrm{S}$ were analyzed on an inductively coupled plasma atomic emission spectrometer (ICP) (Soltanpour et al. 1996). Micronutrients (zinc [Zn], copper [Cu], boron [B], and iron [Fe]) were analyzed via ICP using the method of Gavlak et al. (2003).

Statistical Analyses. The use of replicate zones within the landscape of the larger managed watershed treatments with variable soil characteristics allowed for the creation of uniform zones where responses to management could be more accurately defined. Means, standard deviations, and coefficients of variation $(\mathrm{CV})$ were calculated separately for all measured variables from each of the watersheds (three) by landscape positions (three) by replicate blocks (four).

In addition, the split block design applied in this study allowed us to test for interactions among watershed treatments (three) by landscape positions (three) by replicate blocks (four) by soil depth (three). Data were analyzed as repeated measures in mixed models analyses, with three watershed treatments (management) as main effects, and three landscape positions within paddocks as split-blocks. Soil depth $(n=3)$ was included in the model as a repeated element and was tested with a compound symmetry (CS) covariance matrix to account for autocorrelation and covariance among depths (Littell et al. 1998). Replicate by landscape position interactions were included in the repeated statement as local subjects to order analyses. Fishers least significant difference (LSD) was applied to test significance of main and interaction effects; level of significance for tests was $p=0.05$.

Nonmetric multidimensional scaling (NMDS) was also employed to determine the similarities and differences in a suite of chemical, biological, and physical measures of edaphic properties among treatments and landscape positions at a given depth. "NMDS represents the original position of data in multidimensional space using a reduced number of dimensions that can be plotted and visualized" (Lefcheck 2020). All 
soil variables were log transformed prior to NMDS analyses.

\section{Results and Discussion}

Soil Texture. Variations in scale between soil properties and inherent spatial variability were addressed by the derivation of landform complexes located within uniform zones of management using soil survey and grid-based sampling techniques. The class I soil survey conducted on the WRE confirmed that Bethany (fine, mixed, super active, thermic Pachic Paleustolls) and Renfrow (fine, mixed, super active, thermic Udertic Paleustolls) were the two primary soil series mapped on the watersheds, with smaller interfingering areas of Norge (fine-silty, mixed, active, thermic Udic Paleustolls) present (figure 2). There were no carbonates in any of the soil samples collected to a $30 \mathrm{~cm}$ depth. A pH of 6.0 across all three watershed treatments and landscape positions verified the absence of pedogenic C. Silt loam was the predominant soil texture in all three watersheds (STGP, WWMT, and WWCT) and landscape positions (tread, riser, and toe slopes) at the 0 to $5 \mathrm{~cm}$ and 5 to $15 \mathrm{~cm}$ depths (supplementary tables S1, S2, and S3). Units 1 (STGP) and 8 (WWCT) contained more clay, particularly at the 15 to $30 \mathrm{~cm}$ depth.

The greatest variation in soil series occurred from north to south, and was more prominent in the toe slope position (supplementary tables S1, S2, and S3 and figure 2). However, there was a change in soil series running east to west between the toe and tread slopes, which was noted in watershed units 6 through 8 (WWCT) (figure 2). Despite variations in soil series, each soil type contained comparable mineralogy (illite, montmorillonite, kaolinite, and quartz), and was typically found in similar locations within the landscape of the region (Voss et al. 1978). Additional variability in soil texture was likely due to the interactions among soil series, occurrence of small inclusions of different soils (Williams et al. 1987), land management (grassland versus agronomic), conservation management (vegetative cover, level of disturbance), and erosion. Previous studies on the WRE by Ahuja et al. (1988) and Garbrecht et al. (2015) support the above findings. Other researchers have noted similar patterns where clay content varied due in part to erosion associated with land use (Moges et al. 2013). Golchin and Asgari (2008) found a relationship between

\section{Figure 2}

Map derived from the class I soil survey conducted on the Water Resources Erosion Units (WRE) in November of 2018.

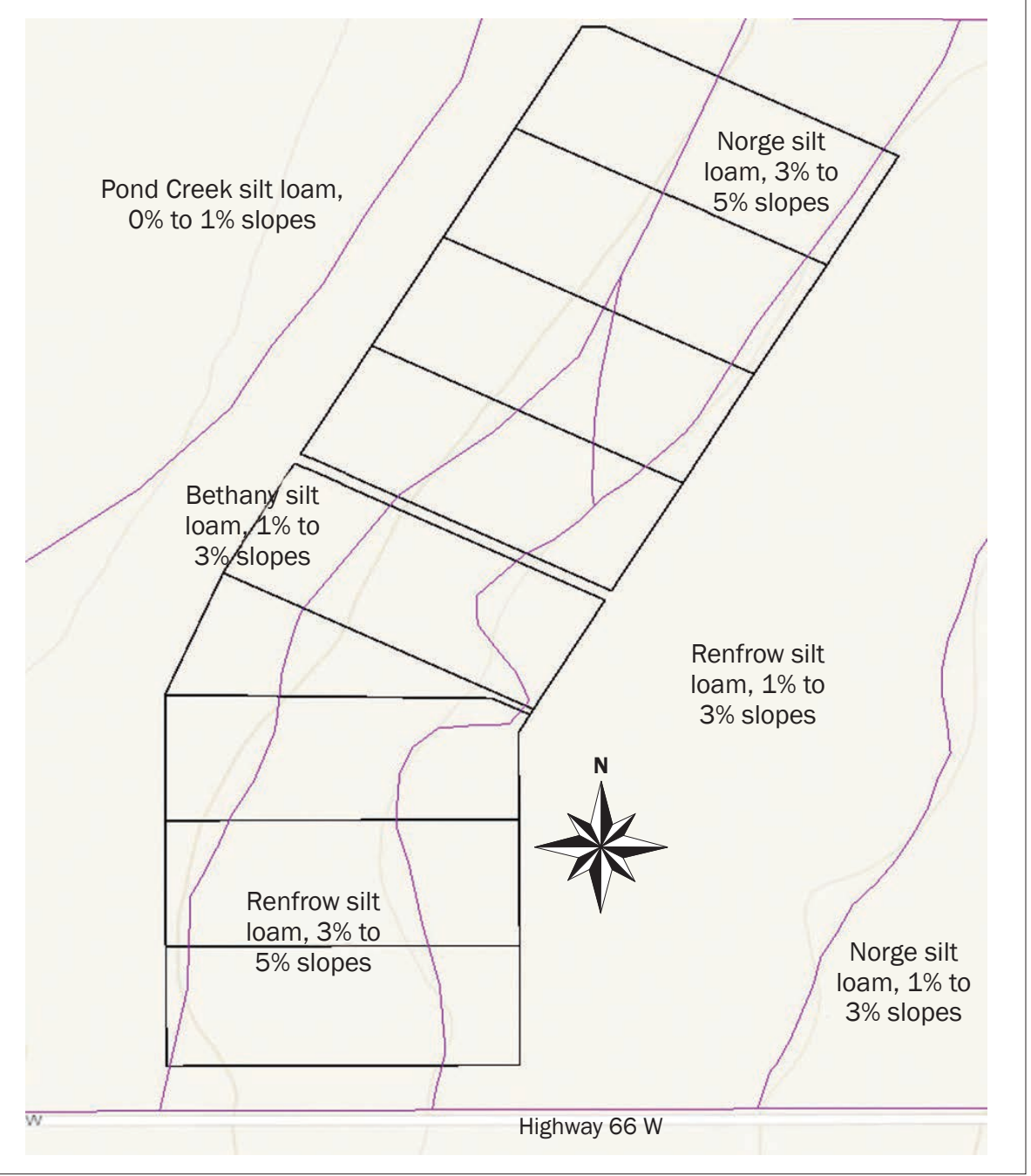

increased clay content in cultivated versus uncultivated soils.

Spatial Variability of Edaphic Properties. The spatial variability of all edaphic measurements are presented as means, standard deviations, and coefficients of variation (CV). The spatial variability of all nutrients by depth, averaged across watershed and landscape position, are available in table 1 . Coefficients of variation for all nutrients except $\mathrm{P}, \mathrm{Zn}, \mathrm{Fe}$, and $\mathrm{Cu}$ ranged between $5 \%$ and $28 \%$ across the three watershed treatments and landscape positions that constituted a 4.8 ha area. Thus, the choice of areas to block by landscape position and watershed reduced the variability of most edaphic properties. The interactive effects of watershed treatment by depth on the spatial variability of TSOC, TSN, $\mathrm{P}_{2} \mathrm{SO}_{4}$, $\mathrm{Ca}$, and $\mathrm{Mg}$ are contained in table 2. The spatial variability of TSOC, TSN, and Ca concentrations were reduced by approximately half when watershed treatment by depth was taken into account. The interactive effects of watershed treatment by depth on the spatial variability of soil $\mathrm{K}, \mathrm{Fe}, \mathrm{Cu}, \mathrm{Zn}$, and $\mathrm{B}$ averaged across treatment by depth are found in table 3 . The spatial variability of nutrients contained in table 3 were similar to the variability in table 1 in which nutrients were averaged across watershed treatment and landscape position. Despite variable landscape position, management, and soil series within the WRE watersheds, $\mathrm{Ca}, \mathrm{Mg}$, TSOC, and TSN (tables 1, 2, and 3) had CV values between 5.11\% and $17.4 \%$ within the 0 to 5,5 to 15 , and 15 to $30 \mathrm{~cm}$ depths. Therefore, further separation of nutrients by landscape position did little 


\section{Table 1}

Spatial variability of all nutrients by depth, averaged across watershed and landscape position as measured by coefficients of variation (CV), means (Average), and standard deviations (SD).

\begin{tabular}{|c|c|c|c|c|}
\hline Nutrient & Depth (cm) & CV & Average & SD \\
\hline \multirow[t]{3}{*}{ TSOC $\left(\mathrm{g} \mathrm{kg}^{-1}\right)$} & 0 to 5 & 18.8 & 27.0 & 5.06 \\
\hline & 5 to 15 & 12.2 & 14.4 & 1.76 \\
\hline & 15 to 30 & 5.11 & 11.3 & 0.58 \\
\hline \multirow[t]{3}{*}{ TSN $\left(\mathrm{g} \mathrm{kg}^{-1}\right)$} & 0 to 5 & 17.4 & 2.31 & 0.40 \\
\hline & 5 to 15 & 11.0 & 1.25 & 0.14 \\
\hline & 15 to 30 & 6.42 & 0.97 & 0.06 \\
\hline \multirow[t]{3}{*}{ Phosphorus (mg kg-1) } & 0 to 5 & 77.9 & 64.4 & 22.5 \\
\hline & 5 to 15 & 53.8 & 19.4 & 5.75 \\
\hline & 15 to 30 & 65.1 & 16.8 & 4.70 \\
\hline \multirow[t]{3}{*}{ Sulfate $\left(\mathrm{mg} \mathrm{kg}^{-1}\right)$} & 0 to 5 & 15.3 & 9.37 & 1.63 \\
\hline & 5 to 15 & 18.7 & 8.63 & 1.81 \\
\hline & 15 to 30 & 27.4 & 7.65 & 2.00 \\
\hline \multirow[t]{3}{*}{ Calcium (mg kg ${ }^{-1}$ ) } & 0 to 5 & 15.4 & 3,059 & 470 \\
\hline & 5 to 15 & 12.5 & 2,809 & 350 \\
\hline & 15 to 30 & 10.9 & 3,093 & 337 \\
\hline \multirow[t]{3}{*}{ Magnesium $\left(\mathrm{mg} \mathrm{kg}^{-1}\right)$} & 0 to 5 & 10.7 & 637 & 68.4 \\
\hline & 5 to 15 & 14.9 & 623 & 92.6 \\
\hline & 15 to 30 & 17.4 & 773 & 135 \\
\hline \multirow[t]{3}{*}{ Potassium (mg kg ${ }^{-1}$ ) } & 0 to 5 & 23.1 & 550 & 127 \\
\hline & 5 to 15 & 30.2 & 295 & 89.1 \\
\hline & 15 to 30 & 20.8 & 224 & 46.7 \\
\hline \multirow[t]{3}{*}{ Iron (mg kg-1) } & 0 to 5 & 25.2 & 68.1 & 17.2 \\
\hline & 5 to 15 & 23.3 & 53.2 & 12.4 \\
\hline & 15 to 30 & 70.3 & 28.7 & 20.1 \\
\hline \multirow[t]{3}{*}{ Copper $\left(\mathrm{mg} \mathrm{kg}^{-1}\right)$} & 0 to 5 & 26.0 & 0.88 & 0.23 \\
\hline & 5 to 15 & 28.8 & 1.16 & 0.33 \\
\hline & 15 to 30 & 36.9 & 1.11 & 0.41 \\
\hline \multirow[t]{3}{*}{ Zinc $\left(\mathrm{mg} \mathrm{kg}^{-1}\right)$} & 0 to 5 & 41.1 & 2.11 & 0.87 \\
\hline & 5 to 15 & 88.1 & 0.38 & 0.34 \\
\hline & 15 to 30 & 60.5 & 0.18 & 0.11 \\
\hline \multirow[t]{3}{*}{ Boron (mg kg-1) } & 0 to 5 & 27.9 & 0.15 & 0.04 \\
\hline & 5 to 15 & 23.6 & 0.13 & 0.03 \\
\hline & 15 to 30 & 16.7 & 0.16 & 0.03 \\
\hline
\end{tabular}

Notes: TSOC $=$ total soil organic carbon. $\mathrm{TSN}=$ total soil nitrogen. Bolded CV $<10$ are very good, italicized 10 to 20 are good, 20 to 30 are acceptable, and CV >30 are not acceptable.

to reduce the variability of nutrients (supplementary tables S4, S5, S6, S7, S8, and S9).

Macro and Secondary Nutrients. The majority of measured variables associated with soil classification and terrain attributes on the WRE varied with depth and landscape position. These variables included clay content, macro ( $\mathrm{P}$ and $\mathrm{K})$, secondary (cations included in base saturation $[\mathrm{Ca}, \mathrm{Mg}, \mathrm{K}]$ and $\mathrm{SO}_{4}-\mathrm{S}$ ), and micronutrients ( $\mathrm{Fe}, \mathrm{Zn}, \mathrm{Cu}$, and B). Phosphorus, $\mathrm{K}$, and $\mathrm{SO}_{4}-\mathrm{S}$ concentrations were highest in the WWCT (Unit 8) at 0 to 5 $\mathrm{cm}$ depth (table 4). The WRE units were not fertilized with $\mathrm{P}$ or $\mathrm{K}$ for a decade prior to soil sampling in 2018, and sulfur in the form of fertilizer was never applied to the WRE.

Soil texture is an integral component of soil fertility and quality assessment that has a direct effect on concentrations of soil macro, secondary, and micronutrients, physical parameters, and water availability (Fine et al. 2017; Hurisso et al. 2018). Land grant universities have conducted nutrient testing for recommendations related to soil fertility on a regional scale for $\sim 80$ years, but only recently at a national level (Lyons et al. 2020). Regional and local variations in soil types, crops, and climate often require different fertility recommendations, and in some instances protocols to extract soil macro, secondary, and micronutrients. Many of these nutrients are also indicators of soil quality reflecting soil condition/productivity, and measured with the same protocols and exhibiting the same spatio-temporal variability (Harisso et al. 2018). Recently, long-term data from different verified sources were aggregated into a national database, the Fertilizer Recommendation Support Tool (FRST). This tool was designed to improve recommendations related to soil fertility, but can also serve to aid in the interpretation of indicators of soil quality included in the Comprehensive Assessment of Soil Health (CASH) (Moebius-Clune et al. 2016).

Increases in $\mathrm{K}$ concentrations at the 0 to $5 \mathrm{~cm}$ depth of the WWCT watershed were likely due to the release of $\mathrm{K}$ from minerals. The textural designations within unit 8 (WWCT) are more variable than units 1 (STGP) and 5 (WWMT) at the 0 to $5 \mathrm{~cm}$ depth (tables S1, S2, and S3). In addition, erosion and disturbance within areas of the WRE have resulted in the removal of part of the organic-rich A horizon, the result of which has been the mixing of the upper portions of the $\mathrm{B}$ horizon into the 0 to 5 cm depth (Ahuja et al. 1988), likely causing an increase in mineral derived K. Previous research on the WRE has verified that tilled winter wheat management increased soil erosion while conservation tillage management coupled with winter wheat and a summer forage mitigated the negative effects of agronomic management on soil erosion (Garbrecht et al. 2015). Sources of K other than fertilizer are primarily clay minerals $(\sim 90 \%)$ and plant residues (Brady and Weil 2008). Greater $\mathrm{K}$ is removed in grain and straw than stored in residues particularly in a tilled monoculture that is grazed and/or hayed. The distribution of $\mathrm{K}$ across a 1,670 $\mathrm{km}^{2}$ area of Switzerland was due to parent material, soil type, and agricultural practices (Blanchet et al. 2017).

Similarly, differences in $\mathrm{P}$ and $\mathrm{SO}_{4}$ concentrations were more likely related to soil mineralogy than the turnover of organic material in SOM and residues. Mollisols in the Great Plains contain sulfur (S) bearing minerals associated with genetic horizons that supply $\mathrm{SO}_{4}$ (Ellert and Bettany 1995). Globally, mineral derived $\mathrm{S}$ is less common than organically bound forms of $\mathrm{S}$ and $\mathrm{S}$ associated from industrial deposition (Brady and Weil 2008).

Concentrations of secondary nutrients (Ca and $\mathrm{Mg}$ ) were significantly higher in unit 1 (STGP) (table 4). Calcium concentrations were greater at all depths of the STGP relative to the WWMT and WWCT treatments (table 4). In contrast, $\mathrm{Mg}$ concentrations associated with $\mathrm{Mg}$ bearing minerals were significantly 
Table 2

The interactive effects of watershed by depth averaged across landscape position on the spatial variability of total soil organic carbon (TSOC), total soil nitrogen (TSN), soil phosphorus (P), sulfate ( $\left.\mathrm{SO}_{4}\right)$, calcium (Ca), and magnesium $(\mathrm{Mg})$ as measured by coefficients of variation (CV), means (Average), and standard deviations (SD).

\begin{tabular}{|c|c|c|c|c|c|}
\hline Nutrient & Watershed treatment & Depth $(\mathrm{cm})$ & CV & Average & SD \\
\hline \multirow[t]{9}{*}{ TSOC $\left(\mathrm{g} \mathrm{kg}^{-1}\right)$} & STGP & 0 to 5 & 7.26 & 29.8 & 2.16 \\
\hline & & 5 to 15 & 4.56 & 15.4 & 0.70 \\
\hline & & 15 to 30 & 4.96 & 11.4 & 0.56 \\
\hline & WWMT & 0 to 5 & 16.8 & 29.6 & 4.97 \\
\hline & & 5 to 15 & 6.31 & 15.6 & 0.99 \\
\hline & & 15 to 30 & 4.53 & 11.1 & 0.50 \\
\hline & WWCT & 0 to 5 & 8.12 & 21.5 & 1.75 \\
\hline & & 5 to 15 & 4.93 & 12.2 & 0.60 \\
\hline & & 15 to 30 & 5.92 & 11.4 & 0.67 \\
\hline \multirow[t]{9}{*}{$\overline{\mathrm{TSN}}\left(\mathrm{g} \mathrm{kg}^{-1}\right)$} & STGP & 0 to 5 & 5.08 & 2.6 & 0.13 \\
\hline & & 5 to 15 & 3.46 & 1.3 & 0.05 \\
\hline & & 15 to 30 & 4.18 & 0.9 & 0.04 \\
\hline & WWMT & 0 to 5 & 14.23 & 2.5 & 0.35 \\
\hline & & 5 to 15 & 6.05 & 1.3 & 0.08 \\
\hline & & 15 to 30 & 5.37 & 1.0 & 0.05 \\
\hline & WWCT & 0 to 5 & 8.67 & 1.9 & 0.16 \\
\hline & & 5 to 15 & 3.61 & 1.1 & 0.04 \\
\hline & & 15 to 30 & 6.18 & 1.0 & 0.06 \\
\hline \multirow[t]{9}{*}{$\overline{\mathrm{P}\left(\mathrm{mg} \mathrm{kg}^{-1}\right)}$} & STGP & 0 to 5 & 11.66 & 13.6 & 1.59 \\
\hline & & 5 to 15 & 15.42 & 6.3 & 0.98 \\
\hline & & 15 to 30 & 19.61 & 4.7 & 0.92 \\
\hline & WWMT & 0 to 5 & 31.04 & 22.4 & 6.95 \\
\hline & & 5 to 15 & 39.19 & 12.9 & 5.05 \\
\hline & & 15 to 30 & 27.36 & 6.6 & 1.81 \\
\hline & WWCT & 0 to 5 & 35.0 & 64.4 & 22.5 \\
\hline & & 5 to 15 & 29.6 & 19.4 & 5.75 \\
\hline & & 15 to 30 & 28.0 & 16.8 & 4.70 \\
\hline \multirow[t]{9}{*}{$\mathrm{SO}_{4}\left(\mathrm{mg} \mathrm{kg}^{-1}\right)$} & STGP & 0 to 5 & 17.7 & 8.32 & 1.47 \\
\hline & & 5 to 15 & 32.1 & 7.97 & 2.55 \\
\hline & & 15 to 30 & 79.9 & 8.38 & 6.70 \\
\hline & WWMT & 0 to 5 & 15.5 & 8.37 & 1.29 \\
\hline & & 5 to 15 & 21.5 & 9.26 & 1.99 \\
\hline & & 15 to 30 & 56.7 & 10.7 & 6.09 \\
\hline & WWCT & 0 to 5 & 22.0 & 10.4 & 2.29 \\
\hline & & 5 to 15 & 23.8 & 10.1 & 2.42 \\
\hline & & 15 to 30 & 71.9 & 8.99 & 6.46 \\
\hline \multirow[t]{9}{*}{$\overline{\mathrm{Ca}\left(\mathrm{mg} \mathrm{kg}^{-1}\right)}$} & STGP & 0 to 5 & 6.02 & 3,602 & 217 \\
\hline & & 5 to 15 & 5.51 & 3,073 & 169 \\
\hline & & 15 to 30 & 5.66 & 3,455 & 196 \\
\hline & WWMT & 0 to 5 & 7.01 & 3,005 & 211 \\
\hline & & 5 to 15 & 12.9 & 2,543 & 327 \\
\hline & & 15 to 30 & 5.81 & 2,865 & 166 \\
\hline & WWCT & 0 to 5 & 6.29 & 2,571 & 162 \\
\hline & & 5 to 15 & 11.3 & 2,810 & 318 \\
\hline & & 15 to 30 & 9.38 & 2,959 & 278 \\
\hline \multirow[t]{9}{*}{$\overline{\mathrm{Mg}\left(\mathrm{mg} \mathrm{kg}^{-1}\right)}$} & STGP & 0 to 5 & 4.49 & 666 & 29.9 \\
\hline & & 5 to 15 & 3.32 & 676 & 22.5 \\
\hline & & 15 to 30 & 6.32 & 921 & 58.2 \\
\hline & WWMT & 0 to 5 & 11.8 & 574 & 67.4 \\
\hline & & 5 to 15 & 14.9 & 536 & 80.0 \\
\hline & & 15 to 30 & 12.5 & 699 & 87.1 \\
\hline & WWCT & 0 to 5 & 8.04 & 671 & 53.9 \\
\hline & & 5 to 15 & 13.5 & 657 & 88.3 \\
\hline & & 15 to 30 & 14.6 & 697 & 102 \\
\hline
\end{tabular}

Notes: STGP $=$ southern tall grass prairie, Unit 1. WWMT = winter wheat, periodic summer forage, minimal disturbance, Unit 5. WWCT $=$ winter wheat, tilled, Unit 8 . Bolded CV $<10$ are very good, italicized 10 to 20 are good, 20 to 30 are acceptable, and $C V>30$ are not acceptable. greater at the 15 to $20 \mathrm{~cm}$ depth of the STGP. A similar trend with depth was found in the WWMT and WWCT treatments. The depth and concentrations of $\mathrm{Ca}$ and $\mathrm{Mg}$ were previously shown to vary with mineralogy, SOM, and inputs of organic material (Takoutsing et al. 2017). As previously mentioned, other researchers have measured higher $\mathrm{K}$ concentrations in no-till systems across a range of soil textures (Franzluebbers and Hons 1996; Karathanasis and Wells 1990). The association of higher $\mathrm{Ca}$ and $\mathrm{Mg}$ concentrations in grasslands has also previously been documented (Frau et al. 2020).

Phosphorus had the greatest variation resulting from the statistically significant interaction between land management and landscape position (table 4). Specifically, unit 8 (WWCT) contained the highest $\mathrm{P}$ concentrations across landscape positions (42 to 30 $\mathrm{mg} \mathrm{kg}^{-1}$ ), unit 5 (WWMT) contained around half as much $\mathrm{P}$ (18 to $11 \mathrm{mg} \mathrm{kg}^{-1}$ ), and unit 1 (STGP) around a third the concentration (9.19 to $7.75 \mathrm{mg} \mathrm{kg}^{-1}$ ) (table 4). Erosion of the Ap horizon is the likely cause of significant increases in $\mathrm{P}$ concentrations in the WWCT management at all landscape positions, $\mathrm{Ca}$ in the toe slope and $\mathrm{SO}_{4}-\mathrm{S}$ at the riser position. Miheretu and Yimer (2018) found a similar pattern in $\mathrm{Ca}$ and $\mathrm{P}$ concentrations between landscape position and land use. Clay minerals that contain and release $\mathrm{SO}_{4}-\mathrm{S}$ and $\mathrm{P}$ are associated with the $\mathrm{B}$ horizon where clay accumulates in the soil solum.

Micronutrients. Terrain attributes had a significant effect on the concentration and location of micronutrients. Boron concentrations were highest in the STGP treatment in the 0 to $5 \mathrm{~cm}$ depth. Boron and $\mathrm{Zn}$ varied significantly due to land management by depth (table 5). Other researchers have confirmed that $\mathrm{Zn}$ concentrations varied by landscape position and depth in four soils ranging from silt loam to silty clay textures (Brubaker et al. 1993). Zinc concentrations were highest in the STGP and WWMT treatments at the 0 to $5 \mathrm{~cm}$ depth. This finding is supported by other no-till research conducted for 8.5 years in a silty clay loam resulting in higher $\mathrm{Zn}$ concentrations than under tilled management (Franzluebbers and Hons 1996) and in an Orthic Humic Gleysol, Brookston clay loam (Van Eerd et al. 2014). Copper and B varied by watershed treatment and landscape position (table 5). Distribution of $\mathrm{Cu}$ with depth followed a similar pattern in a coarse-silty, mixed, super- 
Table 3

The interactive effects of watershed treatment by depth averaged across landscape position on the spatial variability of soil potassium (K), soil iron ( $\mathrm{Fe}$ ), soil copper ( $\mathrm{Cu})$, zinc $(\mathrm{Zn})$, and boron (B) across treatment by depth as measured by coefficients of variation (CV), means (Average), and standard deviations (SD).

\begin{tabular}{|c|c|c|c|c|c|}
\hline Nutrient & Watershed treatment & Depth (cm) & CV & Average & SD \\
\hline \multirow[t]{9}{*}{$\mathrm{K}\left(\mathrm{mg} \mathrm{kg}^{-1}\right)$} & STGP & 0 to 5 & 14.8 & 525 & 77.9 \\
\hline & & 5 to 15 & 22.8 & 314 & 71.7 \\
\hline & & 15 to 30 & 14.5 & 227 & 32.9 \\
\hline & WWMT & 0 to 5 & 19.2 & 468 & 89.6 \\
\hline & & 5 to 15 & 46.1 & 291 & 134 \\
\hline & & 15 to 30 & 27.9 & 237 & 66.0 \\
\hline & WWCT & 0 to 5 & 19.6 & 658 & 129 \\
\hline & & 5 to 15 & 13.5 & 280 & 37.9 \\
\hline & & 15 to 30 & 15.8 & 210 & 33.2 \\
\hline \multirow[t]{9}{*}{$\mathrm{Fe}\left(\mathrm{mg} \mathrm{kg}^{-1}\right)$} & STGP & 0 to 5 & 14.0 & 57.8 & 8.11 \\
\hline & & 5 to 15 & 14.9 & 50.9 & 7.57 \\
\hline & & 15 to 30 & 21.0 & 17.4 & 3.66 \\
\hline & WWMT & 0 to 5 & 33.1 & 71.9 & 23.8 \\
\hline & & 5 to 15 & 29.8 & 53.5 & 15.9 \\
\hline & & 15 to 30 & 31.6 & 14.9 & 4.72 \\
\hline & WWCT & 0 to 5 & 15.1 & 74.7 & 11.3 \\
\hline & & 5 to 15 & 23.2 & 55.4 & 12.8 \\
\hline & & 15 to 30 & 28.4 & 53.6 & 15.2 \\
\hline \multirow[t]{9}{*}{$\mathrm{Cu}\left(\mathrm{mg} \mathrm{kg}^{-1}\right)$} & STGP & 0 to 5 & 11.66 & 13.6 & 1.59 \\
\hline & & 5 to 15 & 15.42 & 6.3 & 0.98 \\
\hline & & 15 to 30 & 19.61 & 4.7 & 0.92 \\
\hline & WWMT & 0 to 5 & 20.6 & 0.76 & 0.16 \\
\hline & & 5 to 15 & 24.5 & 0.92 & 0.22 \\
\hline & & 15 to 30 & 25.8 & 0.94 & 0.24 \\
\hline & WWCT & 0 to 5 & 17.4 & 1.12 & 0.19 \\
\hline & & 5 to 15 & 20.1 & 1.50 & 0.30 \\
\hline & & 15 to 30 & 27.4 & 1.53 & 0.42 \\
\hline \multirow[t]{9}{*}{$\overline{\mathrm{Zn}\left(\mathrm{mg} \mathrm{kg}^{-1}\right)}$} & STGP & 0 to 5 & 11.8 & 2.60 & 0.31 \\
\hline & & 5 to 15 & 19.3 & 0.35 & 0.07 \\
\hline & & 15 to 30 & 36.2 & 0.13 & 0.05 \\
\hline & WWMT & 0 to 5 & 29.7 & 2.63 & 0.78 \\
\hline & & 5 to 15 & 119 & 0.48 & 0.57 \\
\hline & & 15 to 30 & 66.6 & 0.13 & 0.09 \\
\hline & WWCT & 0 to 5 & 10.3 & 1.10 & 0.11 \\
\hline & & 5 to 15 & 21.7 & 0.31 & 0.07 \\
\hline & & 15 to 30 & 34.2 & 0.29 & 0.10 \\
\hline \multirow[t]{9}{*}{$\mathrm{B}\left(\mathrm{mg} \mathrm{kg}^{-1}\right)$} & STGP & 0 to 5 & 14.7 & 0.19 & 0.03 \\
\hline & & 5 to 15 & 5.63 & 0.15 & 0.01 \\
\hline & & 15 to 30 & 10.0 & 0.18 & 0.02 \\
\hline & WWMT & 0 to 5 & 12.5 & 0.16 & 0.02 \\
\hline & & 5 to 15 & 26.5 & 0.11 & 0.03 \\
\hline & & 15 to 30 & 13.8 & 0.15 & 0.02 \\
\hline & WWCT & 0 to 5 & 11.9 & 0.10 & 0.01 \\
\hline & & 5 to 15 & 23.6 & 0.12 & 0.03 \\
\hline & & 15 to 30 & 21.0 & 0.15 & 0.03 \\
\hline
\end{tabular}

Notes: STGP $=$ southern tall grass prairie, Unit 1. WWMT $=$ winter wheat, periodic summer forage, minimal disturbance, Unit 5. WWCT $=$ winter wheat, tilled, Unit 8 . Bolded CV $<10$ are very good, italicized 10 to 20 are good, 20 to 30 are acceptable, and $C V>30$ are not acceptable. active, mesic Typic Haploxeroll (Shiwakoti et al. 2019). Copper was highest in the WWCT treatment on the riser and toe positions. Iron varied with watershed treatment by depth and by landscape position (table 6). Iron was significantly higher or was of a higher concentration in the 0 to $5 \mathrm{~cm}$ depth. The STGP treatment had significantly lower concentrations of Fe relative to the WWCT treatment at all depths and landscape positions (table 6). All of these micronutrients are associated with the constituents' mineralogical micas and feldspars (Singh and Schulze 2015).

Carbon and Nitrogen Indicators Associated with Conservation Management. The repeated measures in mixed models analyses revealed that TSOC,TSN, and POMC varied with management by depth (table 7). Tillage redistributes plant materials, no-till systems stratify nutrients, and prairies concentrate nutrients in the rooting zone (Bruulsema and Ketterings 2008). Specifically, C and N are redistributed within the tilled winter wheat system (WWCT) or stratified within the minimal till and grassland systems (WWMT and STGP) resulting in a management associated artifact. Therefore, soil $\mathrm{C}$ and $\mathrm{N}$ concentrations (TSOC, TSN, and POMC) across managements (STGP, WWMT, and WWCT) were measured and presented on a 0 to $30 \mathrm{~cm}$ depth after concentrations were adjusted for bulk density (table 7).

The lack of a difference in TSOC, TSN, and POMC with landscape position is partly due to the creation of replicate sampling stations within the delineated landform complexes that successfully explained and limited the spatial variability that confounded the interpretation of the effects of soil conservation practices and land use on edaphic measurements. The uniform zones of management sufficiently reduced the variability associated with terrain attributes enabling us to assign the remaining variability to land management and specific conservation practices. Additionally, fertilizer management in the agronomic systems has reduced much of the spatial variability in plant biomass that can be associated with landscape position. Biomass measurements taken in the fall and spring between 2018 and 2020 on WWMT and WWCT varied among managements but did not vary statistically within a treatment (WWMT and WWCT) due to landscape position (data not shown). Other researchers have successfully coupled management zones, precision agriculture, and 


\section{Table 4}

The interactive effects of watershed treatment by depth averaged across landscape position on concentrations of macro and secondary nutrients in soil.

\begin{tabular}{|c|c|c|c|c|c|c|}
\hline \multirow{2}{*}{\multicolumn{2}{|c|}{$\begin{array}{l}\text { Treatment by depth }(\mathrm{cm}) \\
\text { or position }\end{array}$}} & \multicolumn{5}{|c|}{ Macro or secondary nutrients ( $\mathrm{mg} \mathrm{kg}^{-1}$ ) } \\
\hline & & \multirow{2}{*}{$\begin{array}{l}\text { Phosphorus } \\
13.6 \mathrm{c}\end{array}$} & \multirow{2}{*}{$\frac{\text { Potassium }}{525 \mathrm{~b}}$} & \multirow{2}{*}{$\frac{\text { Magnesium }}{666 c}$} & \multirow{2}{*}{$\frac{\text { Calcium }}{3,602 a}$} & \multirow{2}{*}{$\frac{\text { Sulfate }}{8.59 \mathrm{c}}$} \\
\hline STGP & 0 to 5 & & & & & \\
\hline & 5 to 15 & $6.33 d$ & $314 d$ & $676 b c$ & $3,073 c$ & $7.38 d$ \\
\hline & 15 to 20 & $4.68 d$ & $223 e$ & $921 a$ & $3,454 b$ & $6.58 \mathrm{e}$ \\
\hline \multirow[t]{3}{*}{ WWMT } & 0 to 5 & $22.4 b$ & $468 \mathrm{c}$ & $574 d$ & $3,004 c$ & $8.65 c$ \\
\hline & 5 to 15 & $12.9 \mathrm{c}$ & $291 d$ & $536 d$ & $2,543 e$ & $8.78 c$ \\
\hline & 15 to 20 & $6.62 d$ & $237 e$ & $699 b$ & $2,865 d$ & $9.12 b$ \\
\hline \multirow[t]{3}{*}{ WWCT } & 0 to 5 & $64.4 a$ & $658 a$ & $671 b c$ & $2,571 \mathrm{e}$ & $10.6 a$ \\
\hline & 5 to 15 & $19.4 \mathrm{bc}$ & $280 d$ & $657 c$ & $2,810 d$ & $9.73 b$ \\
\hline & 15 to 20 & $16.8 \mathrm{c}$ & $210 \mathrm{e}$ & $697 b$ & $2,959 \mathrm{~cd}$ & $7.24 \mathrm{de}$ \\
\hline \multirow[t]{3}{*}{ STGP } & Tread & $7.75 \mathrm{e}$ & 401ab & $754 a b$ & - & - \\
\hline & Riser & $7.75 \mathrm{e}$ & $336 b c$ & $747 a b$ & - & - \\
\hline & Toe & $9.19 \mathrm{de}$ & $325 c$ & $762 a$ & - & - \\
\hline \multirow[t]{3}{*}{ WWMT } & Tread & $18.2 \mathrm{c}$ & $435 a$ & $522 e$ & - & - \\
\hline & Riser & 11.1de & $272 d$ & $625 d$ & - & - \\
\hline & Toe & $12.6 d$ & $288 \mathrm{~cd}$ & $662 c$ & - & - \\
\hline \multirow[t]{3}{*}{ WWCT } & Tread & $42.2 \mathrm{a}$ & $358 b c$ & $602 d$ & - & - \\
\hline & Riser & $28.6 b$ & $400 a b$ & $728 b$ & - & - \\
\hline & Toe & $29.9 b$ & $390 b$ & $695 c$ & - & - \\
\hline
\end{tabular}

Notes: STGP $=$ southern tall grass prairie, Unit 1. WWMT $=$ winter wheat, periodic summer forage, minimal disturbance, Unit 5. WWCT = winter wheat, tilled, Unit 8. Statistically significant values within a row (univariate two-way ANOVA in PROC MIXED, post hoc: Fischer LSD) are indicated by different letters. $p<0.01$.

conservation practices (Kitchen et al. 2005; Lerch et al. 2005). Increases and decreases of soil $\mathrm{C}$ and $\mathrm{N}$ fractions are the result of the amount of $\mathrm{C}$ and $\mathrm{N}$ returned to the soil as organic material, in this instance plant residues and the rate at which these organic $\mathrm{C}$ and $\mathrm{N}$ fractions decompose (Larson et al. 1972). Disturbance redistributes residues and aids in the fragmentation and oxidation of organic materials, which increase their rate of decomposition (Krull et al. 2003). This is likely the cause of decreasing stocks of $\mathrm{C}$ and $\mathrm{N}$ in the WWCT management of the WRE.

Both the STGP and WWMT managements contained significantly higher concentrations of TSOC, TSN, and POMC than the WWCT management (table 7). Previous research has verified that TSOC, POMC, and RCAH are correlated with one another (Dou et al. 2008). Particulate organic matter C concentrations on the WRE contained between $17 \%$ and $18 \%$ of TSOC. Concentrations of POMC measured across a variety of crop and pasture land ranged from $14 \%$ to $31 \%$ of TSOC (Fortuna et al. 2003b; Dou et al. 2008; Li et al. 2018). Other researchers have measured greater TSOC and POMC after 17 years of no-till versus tilled management in a silt loam (Liu et al. 2014). Badgery et al. (2014) measured higher concentrations of TSOC and POMC in permanent pasture relative to cropland.Although the percentage of POMC in TSOC was not significantly different between managements, the concentrations of POMC varied significantly between managements. The STGP and WWMT managements contained $\sim 15 \%$ more POMC and $\sim 20 \%$ more TSOC and TSN then that of WWCT management. The RCAH fraction in the 0 to $30 \mathrm{~cm}$ depth of crop and grasslands has been previously reported to range from $44 \%$ to $71 \%$ of TSOC (Dou et al. 2008; Fortuna et al. 2003a; Bhowmik et al. 2017). There was a trend, although not statistically significant, indicating that the STGP management contained $\sim 8 \%$ more RCAH than the agronomic managements (WWMT and WWCT).

Although the WWCT contained less POMC than the STGP and WWMT treatments, slightly more of the total $\mathrm{C}$ was contained in the biologically active fraction (POMC) relative to the resistant, nonbiologically active fraction (RCAH). Concentrations of $\mathrm{C}$ contained in the $\mathrm{RCAH}$ fraction in the two agronomic treatments (WWMT and WWCT) were equivalent, although TSOC values were significantly greater in the WWMT treatment. Differences in the quantity of biologically and nonbiologically active fractions among managements relates to how $\mathrm{C}$ and $\mathrm{N}$ are cycled and retained in each system. Tilled agronomic systems tend to retain more $\mathrm{C}$ in active $\mathrm{C}$ fractions with mean turnover rates of days and slow pool turnover rates of years to decades (Paul et al. 1999). In contrast, grasslands and minimally disturbed systems retain more $\mathrm{C}$ in resistant fractions (Paul 1999). Cultivation has been shown to increase $\mathrm{N}$ turnover but not $\mathrm{C}$ turnover in agronomic systems relative to grasslands (Schimel 1986).

Nonmetric Multidimensional Scaling Analyses. The NMDS analyses contain data from all edaphic indicators, not just $\mathrm{C}$ and $\mathrm{N}$. Therefore, TSOC, TSN, POMC, and $\mathrm{N}$ are presented as observations taken from each of the separate soil depths (tables 8, 9, and 10). The NMDS analysis corroborates the significant differences in edaphic properties resulting from interactions among land management, landscape position, and depth represented by the univariate three-way ANOVA.The percentage variation explained by the two NMDS axes are represented by the proximity of the measured variables to the axes in each table. Tables represent the correlation coeficients $(r)$ between the individual variables (edaphic indicators) for a given sampling depth and the two NMDS axes. Significant variables differ from random $(p<0.05)$, reduced stress, and improved the goodness of fit by $\geq 0.050$, which is in the range of good to excellent (Šmilauer and Lepš 2014). Edaphic properties that correlated with one or both axes displayed in a table had absolute $r$ values greater than 0.50 and are bolded.

The NMDS analysis verified that texture, chemical (P, K, Ca, $\mathrm{SO}_{4}, \mathrm{Zn}$, and $\left.\mathrm{B}\right)$, and biological (TSN and TSOC) edaphic indicators contributed to the variability of axis 1 within the 0 to $5 \mathrm{~cm}$ depth (table 8). In contrast, the variability of axis 2 related to $\mathrm{Fe}$ concentrations. Other researchers have observed an increase in total $\mathrm{P}$ in cropland relative to grassland (Gosling et al. 2017), and that land use is a primary driver of $\mathrm{P}$ variability at the field and watershed scales (Page et al. 2005). Cade-Menun et al. (2017) measured higher $\mathrm{Zn}$ concentrations in grassland relative to cropland that also varied with depth. Iron could be higher in agronomic managements 
Table 5

The interactive effects of watershed treatment by depth averaged across landscape position on concentrations of micronutrients in soil.

\begin{tabular}{|c|c|c|c|c|}
\hline \multirow{2}{*}{\multicolumn{2}{|c|}{ Treatment by depth (cm) or position }} & \multicolumn{3}{|c|}{ Micronutrients (mg kg ${ }^{-1}$ ) } \\
\hline & & \multirow{2}{*}{$\frac{\text { Zinc }}{2.70 a}$} & \multirow{2}{*}{$\frac{\text { Boron* }}{0.19 a}$} & \multirow{2}{*}{$\frac{\text { Copper }}{-}$} \\
\hline STGP & 0 to 5 & & & \\
\hline & 5 to 15 & $0.45 c$ & $0.15 b$ & - \\
\hline & 15 to 20 & $0.12 d$ & $0.18 a$ & - \\
\hline \multirow[t]{3}{*}{ WWMT } & 0 to 5 & $2.63 a$ & $0.16 \mathrm{~b}$ & - \\
\hline & 5 to 15 & $0.48 c$ & $0.11 c$ & - \\
\hline & 15 to 20 & $0.13 d$ & $0.15 b$ & - \\
\hline \multirow[t]{3}{*}{ WWCT } & 0 to 5 & $1.20 \mathrm{~b}$ & $0.10 c$ & - \\
\hline & 5 to 15 & $0.31 \mathrm{~cd}$ & $0.12 c$ & - \\
\hline & 15 to 20 & $0.29 \mathrm{~cd}$ & $0.15 b$ & - \\
\hline \multirow[t]{3}{*}{ STGP } & Tread & - & $0.18 a$ & $0.92 \mathrm{~cd}$ \\
\hline & Riser & - & $0.17 a b$ & $0.92 \mathrm{~cd}$ \\
\hline & Toe & - & $0.18 a$ & $0.88 d$ \\
\hline \multirow[t]{3}{*}{ WWMT } & Tread & - & $0.13 c$ & $0.82 d$ \\
\hline & Riser & - & $0.15 b$ & $0.78 d$ \\
\hline & Toe & - & $0.14 b$ & $1.02 \mathrm{c}$ \\
\hline \multirow[t]{3}{*}{ WWCT } & Tread & - & $0.12 c$ & $1.55 a$ \\
\hline & Riser & - & $0.12 c$ & $1.23 b$ \\
\hline & Toe & - & $0.12 \mathrm{c}$ & $1.36 \mathrm{~b}$ \\
\hline
\end{tabular}

Notes: STGP = southern tall grass prairie, Unit 1. WWMT = winter wheat, periodic summer forage, minimal disturbance, Unit 5. WWCT = winter wheat, tilled, Unit 8. Statistically significant values within a row (univariate two-way ANOVA in PROC MIXED, post hoc: Fischer LSD) are indicated by different letters. $p<0.01$.

* For treatment by depth, statistically significant values within a row (univariate two-way ANOVA in PROC MIXED, post hoc: Fischer LSD) are indicated by different letters. $p<0.05$.

\section{Table 6}

The interactive effects of watershed treatment by landscape position and by depth on soil iron concentrations $\left(\mathrm{mg} \mathrm{kg}^{-1}\right)$.

\begin{tabular}{llll}
\hline & \multicolumn{2}{l}{ Depth $\mathbf{( c m})$} & \\
\cline { 4 - 4 } Landscape position/watershed treatment & $\mathbf{0}$ to $\mathbf{5}$ & $\mathbf{5}$ to $\mathbf{1 5}$ & $\mathbf{1 5}$ to $\mathbf{2 0}$ \\
\hline Tread & & & \\
STGP & $66.1 \mathrm{~cd}$ & $50.6 \mathrm{de}$ & $14 \mathrm{gh}$ \\
WWMT & $42.4 \mathrm{e}$ & $33.5 \mathrm{f}$ & $10.3 \mathrm{~h}$ \\
WWCT & $81.6 \mathrm{~b}$ & $65 \mathrm{~cd}$ & $54.5 \mathrm{de}$ \\
Riser & & & \\
STGP & $53.1 \mathrm{de}$ & $47.1 \mathrm{e}$ & $17.8 \mathrm{gh}$ \\
WWMT & $95.2 \mathrm{a}$ & $68.6 \mathrm{c}$ & $15.4 \mathrm{gh}$ \\
WWCT & $67.8 \mathrm{c}$ & $52.6 \mathrm{de}$ & $50.5 \mathrm{de}$ \\
Toe & & & \\
STGP & $54.1 \mathrm{de}$ & $54.9 \mathrm{de}$ & $20.5 \mathrm{~g}$ \\
WWMT & $78.0 \mathrm{~b}$ & $58.3 \mathrm{~d}$ & $19.1 \mathrm{~g}$ \\
WWCT & $74.6 \mathrm{bc}$ & $48.5 \mathrm{e}$ & $55.8 \mathrm{de}$ \\
\hline
\end{tabular}

Notes: STGP = southern tall grass prairie, Unit 1. WWMT = winter wheat, periodic summer forage, minimal disturbance, Unit 5. WWCT $=$ winter wheat, tilled, Unit 8. Statistically significant values within a column for each position (univariate two-way ANOVA in PROC MIXED, post hoc: Fischer LSD) are indicated by different letters. $p<0.01$.

due to crop residues, trace amounts of Fe in fertilizer applications, and erosion of the plow layer resulting in increased clay minerals that contain Fe. Total SOC and TSN explained a similar proportion of the variation in axis 1 at the 0 to $5 \mathrm{~cm}$ depth (table 8). Given the same climate and soil type, prairie and other uncultivated soils are typically higher in TSOC and TSN. Cultivation particularly when coupled with disturbance such as tillage reduces $\mathrm{C}$ and $\mathrm{N}$ fractions $>20$ $\mu \mathrm{m}$, a fraction that includes POM (Hassink 1997). Therefore, POM fractions provide a more rapid (one to four year) assessment of a management practice on soil $\mathrm{C}$ and $\mathrm{N}$ that can be used as a positive, neutral, or negative indicator by land managers.

The majority of the variability in axis 1 of the 5 to $15 \mathrm{~cm}$ depth was correlated with edaphic parameters associated with inorganic soil properties, while axis 2 correlated strongly with $\mathrm{C}$ and $\mathrm{N}$ stocks (table 9). Phosphorus, $\mathrm{SO}_{4}-\mathrm{S}, \mathrm{Ca}$, and $\mathrm{Mg}$ partially explained the variation in axis 1 , and $\mathrm{K}$ partially explained the variation in axis 2 . Micronutrients explained a portion of the variation in axis $1(\mathrm{~B})$ and axis $2(\mathrm{Zn})$. TSOC, TSN, POMC, and N explained the majority of the variability in axis 2 . As previously noted, tillage disturbance, nutrient stratification in no-till, and the distribution of roots in the STGPs were the cause of the overlapping treatment observations. The 5 to 15 $\mathrm{cm}$ depth is subject to mixing and inconsistent redistribution of residues in the WWCT treatment and contains the majority of plant roots in all treatments.

Inorganic edaphic indicators were correlated with the variability of axis 1 and 2 at the 15 to $30 \mathrm{~cm}$ depth. Phosphorus, $\mathrm{Mg}$, $\mathrm{Fe}$, and $\mathrm{Zn}$ partially explained the variation in axis 1 , and texture, $\mathrm{K}, \mathrm{SO}_{4}-\mathrm{S}, \mathrm{Ca}$, and $\mathrm{Mg}$ partially explained the variation in axis 2 (table 10).

\section{Summary and Conclusions}

A number of soil fertility measurements analyzed for decades are also used as measures of soil quality, varying on the same spatial scale. These include macro, secondary, and micronutrients that differ due to taxonomic properties, terrain attributes, and conservation practices. The majority of variables associated with soil classification and terrain attributes on the WRE varied with depth and landscape position. Measurements 


\section{Table 7}

Integrators of land use and inherent soil properties at o to $30 \mathrm{~cm}$ depth: total soil organic carbon (TSOC), resistant fraction of soil organic C measured via the residual $\mathrm{C}$ of acid hydrolysis (RCAH), RCAH as a percentage of TSOC, particulate organic matter C (POMC), and percentage POMC as a percentage of TSOC.

\begin{tabular}{|c|c|c|c|c|c|}
\hline Treatment description & TSOC $\left(\mathrm{g} \mathrm{kg}^{-1}\right)$ & $\mathrm{RCAH}\left(\mathrm{g} \mathrm{kg}^{-1}\right)$ & RCAH as a percentage of TSOC (\%) & POMC $\left(\mathrm{g} \mathrm{kg}^{-1}\right)$ & POMC in TSOC (\%) \\
\hline $\begin{array}{l}\text { Winter wheat, tilled, } \\
\text { Unit } 8 \text { (WWCT) }\end{array}$ & $15 b$ & 8 & 54 & $2.71 b$ & 18 \\
\hline
\end{tabular}

Notes: Statistically significant values within a column (univariate two-way ANOVA in PROC MIXED, post hoc: Fischer LSD) are indicated by different letters. $p<0.01$.

\section{Table 8}

Nonmetric multidimensional scaling (NMDS) analysis of edaphic indicators at the o to $5 \mathrm{~cm}$ depth measuring the effects of land management and landscape position. Correlation coefficients $(r)$ resulting from correlations between measured variables and each NMDS axis.

\begin{tabular}{lrr}
\hline & \multicolumn{1}{l}{$\boldsymbol{r}$} & \\
\cline { 2 - 3 } Edaphic properties (soil quality indicators) & Axis 1 & Axis 2 \\
\hline Sand & $\mathbf{- 0 . 5 2 5 8}$ & 0.0611 \\
Clay & $\mathbf{0 . 5 9 2 4}$ & -0.1569 \\
pH & $\mathbf{- 0 . 9 5 1 8}$ & 0.1460 \\
Phosphorus & $\mathbf{0 . 9 3 1 4}$ & -0.1098 \\
Potassium & $\mathbf{0 . 6 2 4 6}$ & 0.3995 \\
Sulfate & $\mathbf{0 . 6 9 7 7}$ & -0.3176 \\
Calcium & $\mathbf{- 0 . 8 5 7 8}$ & 0.0671 \\
Magnesium & 0.1878 & -0.1943 \\
Iron & 0.2907 & $-\mathbf{0 . 8 0 8 9}$ \\
Zinc & $\mathbf{- 0 . 8 7 5 7}$ & -0.2139 \\
Boron & $\mathbf{- 0 . 8 8 2 8}$ & -0.0847 \\
Total soil nitrogen & $\mathbf{- 0 . 8 6 0 0}$ & -0.3242 \\
Total soil organic carbon & $\mathbf{- 0 . 8 2 5 7}$ & -0.3499 \\
Particulate organic matter nitrogen & 0.2886 & -0.3358 \\
Particulate organic matter carbon & -0.2172 & -0.3248 \\
\hline
\end{tabular}

Note: Values that are bolded are interpretable for a given axis.

included clay content, macro ( $\mathrm{P}$ and $\mathrm{K})$, secondary (cations included in base saturation $[\mathrm{Ca}, \mathrm{Mg}$, and $\mathrm{K}]$ and $\left.\mathrm{SO}_{4}-\mathrm{S}\right)$, and micronutrients [ $\mathrm{Fe}, \mathrm{Zn}, \mathrm{B}$, and $\mathrm{Cu}]$ ).

The uniform zones of management delineated using a class I soil survey, grid, and zone sampling sufficiently reduced the variability associated with terrain attributes, enabling us to assign the remaining variability in edaphic properties to land management and specific conservation practices. As a result, TSOC, TSN, and POMC (the sand-sized soil separates remaining on a $53 \mu \mathrm{m}$ sieve) did not vary with landscape position. Cultivation particularly in the tilled treatment reduced soil $\mathrm{C}$ and $\mathrm{N}$ fractions. The sand associated $\mathrm{C}$ fraction that includes POMC provided a rapid (one to four year) assessment of conservation management practices effects on edaphic properties used to measure soil quality. Use of a suite of edaphic indicators that vary significantly and others that remain constant with soil classification and terrain attributes, land management, and specific conservation practices can aid land managers to quickly assess whether transitions in land use and management have a positive, neutral, or negative effect.
Our efforts to parameterize the inherent spatial variability of these watersheds in order to determine the effects of land management on soil quality were successful. We established replicate sampling stations within defined landform complexes to explain and limit spatial variability that confounds researchers' interpretation of the effects of soil conservation practices and land use on soil quality measurements. Current measurements provide information with respect to soil properties that affect water $\left(\mathrm{H}_{2} \mathrm{O}\right)$ movement, soil fertility, and plant nutrient efficiency, which can directly influence $\mathrm{H}_{2} \mathrm{O}$ runoff and quality. Future work will include use of in-situ near infrared (NIRS) technology coupled with a set of soil quality measures calibrated against NIRS scans to verify that measures of soil quality can be predicted using NIRS and a minimal data set (Fortuna et al. 2019). Measurements collected from the $4.6 \mathrm{~m}$ by $3.8 \mathrm{~m}$ replicated sized spatial zones created in this study will be used to validate agricultural models like the Agricultural Policy/Environmental eXtender Model (APEX) to predict the effects of alternative land management on water quality.

\section{Supplemental Material}

The supplementary material for this article is available in the online journal at https://doi.org/10.2489/jswc.2022.00160.

\section{Acknowledgements}

This research contributed to the Conservation Effects Assessment Project and is a contribution of the USDA Agricultural Research Service (ARS) Southern Plains Long-Term Agroecosystem Research Site. We also thank Jeremy Dennis and Jarred Goedeke (soil scientists, Stillwater Soil Survey Office, Stillwater, Oklahoma) for providing us the Class I Soil Survey. Research was funded by the United States Department of Agriculture. 
Table 9

Nonmetric multidimensional scaling (NMDS) analysis of edaphic indicators at the 5 to $15 \mathrm{~cm}$ depth measuring the effects of land management and landscape position. Correlation coefficients $(r)$ resulting from correlations between measured variables and each NMDS axis.

\begin{tabular}{lrr}
\hline & \multicolumn{1}{l}{$\boldsymbol{r}$} \\
\cline { 2 - 3 } Edaphic properties (soil quality indicators) & Axis 1 & Axis 2 \\
\hline Sand & 0.4776 & 0.1155 \\
Clay & 0.1271 & -0.2515 \\
pH & $\mathbf{- 0 . 7 1 3 9}$ & 0.3902 \\
Phosphorus & $\mathbf{0 . 9 4 1 7}$ & -0.0972 \\
Potassium & 0.2201 & $\mathbf{0 . 7 1 8 7}$ \\
Sulfate & $\mathbf{0 . 6 9 3 8}$ & -0.1713 \\
Calcium & $\mathbf{- 0 . 5 2 2 7}$ & 0.0315 \\
Magnesium & $\mathbf{- 0 . 5 2 4 0}$ & -0.3605 \\
Iron & -0.0734 & -0.3642 \\
Zinc & 0.3323 & $\mathbf{0 . 5 1 9 8}$ \\
Boron & $\mathbf{- 0 . 5 6 5 1}$ & 0.0568 \\
Total soil nitrogen & -0.0497 & $\mathbf{0 . 7 1 6 2}$ \\
Total soil organic carbon & -0.1639 & $\mathbf{0 . 7 1 9 7}$ \\
Particulate organic matter nitrogen & -0.3383 & $\mathbf{0 . 6 2 4 9}$ \\
Particulate organic matter carbon & $\mathbf{- 0 . 6 3 0 5}$ & $\mathbf{0 . 5 8 9 2}$ \\
\hline
\end{tabular}

Note: Values that are bolded are interpretable for a given axis.

\section{Table 10}

Nonmetric multidimensional scaling (NMDS) analysis of edaphic indicators at the 15 to $30 \mathrm{~cm}$ depth measuring the effects of land management and landscape position. Correlation coefficients $(r)$ resulting from correlations between edaphic properties and each NMDS axis.

\begin{tabular}{lrr}
\hline & \multicolumn{1}{r}{} & \\
\cline { 2 - 3 } Edaphic properties (soil quality indicators) & Axis 1 & Axis 2 \\
\hline Sand & 0.0622 & $\mathbf{- 0 . 8 3 8 0}$ \\
Clay & 0.0862 & $\mathbf{- 0 . 7 0 7 9}$ \\
$\mathrm{pH}$ & $\mathbf{- 0 . 9 0 3 9}$ & -0.2456 \\
Phosphorus & $\mathbf{0 . 9 2 9 7}$ & 0.2170 \\
Potassium & -0.2050 & $\mathbf{0 . 5 6 6 4}$ \\
Sulfate & -0.0283 & $\mathbf{0 . 8 4 4 9}$ \\
Calcium & -0.4567 & $\mathbf{- 0 . 6 5 9 9}$ \\
Magnesium & $\mathbf{- 0 . 5 7 3 2}$ & $\mathbf{- 0 . 7 3 3 2}$ \\
Iron & $\mathbf{0 . 9 2 3 5}$ & -0.2859 \\
Zinc & $\mathbf{0 . 7 1 6 7}$ & 0.1180 \\
Boron & -0.4278 & -0.3533 \\
Total soil nitrogen & 0.7170 & 0.1376 \\
Total soil organic carbon & 0.1761 & -0.2700 \\
Particulate organic matter nitrogen & $\mathbf{0 . 5 2 6 8}$ & $\mathbf{- 0 . 5 3 5 1}$ \\
Particulate organic matter carbon & -0.2940 & -0.4939 \\
\hline
\end{tabular}

Note: Values that are bolded are interpretable for a given axis.

\section{Disclaimers}

Mention of trade names or commercial products in this publication is solely for the purpose of providing specific information and does not imply recommendation or endorsement by the US Department of Agriculture (USDA). The USDA prohibits discrimination in all its programs and activities on the basis of race, color, national origin, age, disability, and where applicable, sex, marital status, familial status, parental status, religion, sexual orientation, genetic information, political beliefs, reprisal, or because all or part of an individual's income is derived from any public assistance program. USDA is an equal opportunity provider and employer.

\section{References}

Ahuja, L.R., J.W. Naney, R.D. Williams, and J.D. Ross. 1988. Vertical variability of soil properties in a small watershed. Journal of Hydrology 99(3-4):307-318.

Allen, D.E., M.J. Pringle, K.L. Page, and R.C. Dalal. 2010. A review of sampling designs for the measurement of soil organic carbon in Australian grazing lands. The Rangeland Journal 32(2):227-246.

Badgery,W.B., A.T. Simmons, B.W. Murphy,A. Rawson, K.O. Andersson, and V.E. Lonergan. 2014. The influence of land use and management on soil carbon levels for croppasture systems in Central New South Wales, Australia. Agriculture, Ecosystems \& Environment 196:147-157.

Bauer, P.J., J.R. Frederick, W.J. Busscher, and S.E. Van. 2002. Optimizing conservation tillage production: Soil specific effects of management practices on cotton, soybean, and wheat. In Making Conservation Tillage Conventional: Building a Future on 25 Years of Research. Proceedings of 25th Annual Southern Conservation Tillage Conference for Sustainable Agriculture, Auburn, AL, USA, 24-26 June, 2002.

Bhowmik, A., A.M. Fortuna, L.J. Cihacek, A.I. Bary, P.M. Carr, and C.G. Cogger. 2017. Potential carbon sequestration and nitrogen cycling in long-term organic management systems. Renewable Agriculture and Food Systems 32(6):498-510.

Blake, G.R., and K.H. Hartge. 1986. Bulk density. Methods of soil analysis: Part 1 Physical and Mineralogical Methods 5:363-375.

Blanchet, G., Z. Libohova, S. Joost, N. Rossier, A. Schneider, B. Jeangros, and S. Sinaj. 2017. Spatial variability of potassium in agricultural soils of the canton of Fribourg, Switzerland. Geoderma 290:107-121.

Brady, N.C., and R.R.Weil. 2008. The Nature and Properties of Soils, Volume 13, p. 662-710. Upper Saddle River, NJ: Prentice Hall.

Brubaker, S.C., A.J. Jones, D.T. Lewis, and K. Frank. 1993. Soil properties associated with landscape position. Soil Science Society of America Journal 57(1):235-239.

Bruulsema, T.W., and Q. Ketterings. 2008. Fertilizer BMPsBest Management for Fertilizers on Northeastern Dairy Farms. Norcross, GA: International Plant Nutrition Institute. Burke, I.C., E.T. Elliott, and C.V. Cole. 1995. Influence of macroclimate, landscape position, and management on soil organic matter in agroecosystems. Ecological Applications 5(1):124-131.

Cade-Menun, B.J., L.D. Bainard, K. LaForge, M. Schellenberg, B. Houston, and C. Hamel. 2017. Long-term agricultural land use affects chemical and physical properties of soils from southwest Saskatchewan. Canadian Journal of Soil Science 97(4):650-666. 
Cambardella, C.A., and E.T. Elliott. 1993. Carbon and nitrogen distribution in aggregates from cultivated and native grassland soils. Soil Science Society of America Journal 57:1071-1076.

Daniel, J. 2001. The water resources and erosion watersheds, Fort Reno, OK. USDA ARS Research Report GRL 1-01: El Reno, OK: USDA Agricultural Research Service Grazinglands Research Laboratory.

Delgado, J.A., P.M. Groffman, M.A. Nearing, T. Goddard, D. Reicosky, R. Lal, N.R. Kitchen, C.W. Rice, D. Towery, and P. Salon. 2011. Conservation practices to mitigate and adapt to climate change. Journal of Soil and Water Conservation 66(4):118A-129A. https://doi. org/10.2489/jswc.66.4.118A.

Doran, J.W., T.B. Parkin, and A.J. Jones. 1996. Quantitative indicators of soil quality: A minimum data set. In Methods for Assessing Soil Quality, SSSA Special Publication No. 49:25-37. Madison, WI: Soil Science Society of America.

Dou, F., A.L. Wright, and F.M. Hons. 2008. Sensitivity of labile soil organic carbon to tillage in wheat-based cropping systems. Soil Science Society of America Journal 72(5):1445-1453.

Duriancik, L.F, D. Bucks, J.P. Dobrowolski, T. Drewes, S.D. Eckles, L. Jolley, R.L. Kellogg, D. Lund, J.R. Makuch, M.P. O'Neill, and C.A. Rewa. 2008. The first five years of the Conservation Effects Assessment Project. Journal of Soil and Water Conservation 63(6):185A-197A. https://doi.org/10.2489/jswc.63.6.185A.

Ellert, B.H., and J.R. Bettany. 1995. Calculation of organic matter and nutrients stored in soils under contrasting management regimes. Canadian Journal of Soil Science 75(4):529-538.

Fine, A.K., H.M. van Es, and R.R. Schindelbeck. 2017. Statistics, scoring functions, and regional analysis of a comprehensive soil health database. Soil Science Society of America Journal 81(3):589-601.

Fortuna, A., A. Bhowmik, A. Bary, and C. Cogger. 2018. Biological indicators of soil health in organic cultivation. In Managing Soil Health for Sustainable Agriculture, Volume 2: Monitoring and Management, ed. D. Reicosky, 43-55. Cambridge, UK: Burleigh Dodds Science Publishing. http://dx.doi.org/10.19103/ AS.2017.0033.19

Fortuna, A., R. Harwood, K. Kizilkaya, and E.A. Paul. 2003a. Optimizing nutrient availability and potential carbon sequestration in an agroecosystem. Soil Biology and Biochemistry 35(8):1005-1013.

Fortuna,A., R.R. Harwood, and E.A. Paul. 2003b.The effects of compost and crop rotations on carbon turnover and the particulate organic matter fraction. Soil Science 168(6):434-444.

Fortuna, A.M., P.J. Starks, A.M. Nelson, and J.L. Steiner. 2019. Prediction of soil carbon fractions using a field spectroradiometer equipped with an illuminating contact probe. Soil Systems 3(4):71-85.
Franzluebbers, A.J., and F.M. Hons. 1996. Soil-profile distribution of primary and secondary plant-available nutrients under conventional and no tillage. Soil \& Tillage Research (39):229-239.

Frau, L.J., Z. Libohova, S. Joost, C. Levasseur, B. Jeangros, L. Bragazza, and S. Sinaj. 2020. Regional investigation of spatial-temporal variability of soil magnesium-A case study from Switzerland. Geoderma Regional 21:00278.

Garbrecht, J.D., M.A. Nearing, J.L. Steiner, X.J. Zhang, and M.H. Nichols. 2015. Can conservation trump impacts of climate change on soil erosion? An assessment from winter wheat cropland in the Southern Great Plains of the United States. Weather and Climate Extremes (10):32-39.

Gavlak, R., D. Hornect, R. Miller, and J. Kotuby-Amacher. 2003. Soil, Plant, and Water Reference Methods for the Western Region, 2nd edition. WCC-103 Publication. Fort Collins, CO.

Gee, G.W., and J.W. Bauder. 1986. Particle-Size Analysis. In Methods of Soil Analysis Part 1, ed. A. Klute, 383-411. SSSA Book Series 5. Madison, WI: Soil Science Society of America.

Golchin, A., and H. Asgari. 2008. Land use effects on soil quality indicators in north-eastern Iran. Soil Research 46(1):27-36.

Gosling, P., C. Van Der Gast, and G.D. Bending. 2017. Converting highly productive arable cropland in Europe to grassland: A poor candidate for carbon sequestration. Scientific Reports 7(1):1-12.

Gregorich, E.G., M.H. Beare, and M.R. Carter. 2008. Physically uncomplexed organic matter. In Soil Sampling and Methods of Analysis, 607-616. Boca Raton, FL: CRC Press.

Hassink, J. 1997. The capacity of soils to preserve organic C and $\mathrm{N}$ by their association with clay and silt particles. Plant and Soil 191(1):77-87.

Huluka, G., and R. Miller. 2014. Chapter 6.3: Particle size determination by hydrometer method. Southern Cooperative Series Bulletin 419, p.180-184. Southern Extension and Research Activity Information Exchange Group.

Hurisso, T.T., D.J. Moebius-Clune, S.W. Culman, B.N. Moebius-Clune, J.E. Thies, and H.M. van Es. 2018. Soil protein as a rapid soil health indicator of potentially available organic nitrogen.Agricultural \& Environmental Letters 3(1):1-5.

Karathanasis,A.D., and K.L.Wells. 1990. Conservation tillage effects on the potassium status of some Kentucky soils. Soil Science Society of America Journal 54(3):800-806.

Killham, K., and W.J. Staddon. 2002. Bioindicators and sensors of soil health and the application of geostatistics. In Enzymes in the Environment, 391-405. New York: Marcel Dekkerr.

Kitchen, N.R., K.A. Sudduth, D.B. Myers, R.E. Massey, E.J. Sadler, R.N. Lerch, J.W. Hummel, and H.L. Palm. 2005. Development of a conservation-oriented precision agriculture system: Crop production assessment and plan implementation. Journal of Soil and Water Conservation 60(6):421-430.

Kleinman, P.J.A., S. Spiegal, J.R. Rigby, S.C. Goslee, J.M. Baker, B.T. Bestelmeyer, R.K. Boughton, R.B. Bryant, M.A. Cavigelli, J.D. Derner, E.W. Duncan, D.C. Goodrich, D.R. Huggins, K.W. King, M.A. Liebig, M.A. Locke, S.B. Mirsky, G.E. Moglen, T.B. Moorman, F.B. Pierson, G.P. Robertson, E.J. Sadler, J.S. Shortle, J.L. Steiner, T.C. Strickland, H.M. Swain, T. Tsegaye, M.R. Williams, and C.L. Walthall. 2019. Advancing the Sustainability of US Agriculture through Long-Term Research. Journal of Environmental Quality 47:6:14121425. https://doi:10.2134/jeq2018.05.0171.

Krull, E.S., J.A. Baldock, and J.O. Skjemstad. 2003. Importance of mechanisms and processes of the stabilisation of soil organic matter for modelling carbon turnover. Functional Plant Biology 30(2):207-222.

Lal, R., J.A. Delgado, P.M. Groffman, N. Millar, C. Dell, and A. Rotz. 2011. Management to mitigate and adapt to climate change. Journal of Soil and Water Conservation 66(4):276-285. https://doi.org/10.2489/jswc.66.4.276.

Larson, W., C.E. Clapp, W.H. Pierre, and Y.B. Morachan. 1972. Effects of increasing amounts of organic residues on continuous corn: II. Organic carbon, nitrogen, phosphorus, and sulfur 1. Agronomy Journal 64(2):204-209.

Larson, W.E., and F.J. Pierce. 1991. Conservation and enhancement of soil quality. In Evaluation for Sustainable Land Management in the Developing World, Vol. 2: Technical papers, 175-203. Bangkok, Thailand: International Board for Research and Management.

Lawson, A., A.M. Fortuna, C. Cogger, A. Bary, and T. Stubbs. 2013. Nitrogen contribution of rye-hairy vetch cover crop mixtures to organically grown sweet corn. Renewable Agriculture and Food Systems 28(1):59-69.

Lefcheck, J. 2020. NMDS Tutorial in R. Sample(Ecology). https://jonlefcheck.net/2012/10/24/ nmds-tutorial-in-r/.

Lerch, R.N., N.R. Kitchen, R.J. Kremer, W.W. Donald, E.E. Alberts, E.J. Sadler, K.A. Sudduth, D.B. Myers, and F. Ghidey. 2005. Development of a conservation-oriented precision agriculture system: Water and soil quality assessment. Journal of Soil and Water Conservation 60(6):411-421

Li,J., G.H.Ramirez, M. Kiani, S. Quideau, E.Smith, H.Janzen, F. Larney, and D. Puurveen. 2018. Soil organic matter dynamics in long-term temperate agroecosystems: Rotation and nutrient addition effects. Canadian Journal of Soil Science 98(2):232-245.

Littell, R.C., G.A. Milliken,W.W. Stroup, and R.D.Wolfinger. 1996. SAS System for Mixed Models. Cary, NC: SAS Institute, Inc.

Liu, E., S.G. Teclemariam, C. Yan, J. Yu, R. Gu, S. Liu, W. $\mathrm{He}$, and Q. Liu. 2014. Long-term effects of no-tillage management practice on soil organic carbon and its fractions in the northern China. Geoderma 213:379-384 
Liu, D., Z. Wang, B. Zhang, K. Song, X. Li, J. Li, F. Li, and H. Duan. 2006. Spatial distribution of soil organic carbon and analysis of related factors in croplands of the black soil region, Northeast China. Agriculture, Ecosystems \& Environment 113(1-4):73-81.

Lyons, S.E., D.L. Osmond, N.A. Slaton, J.T. Spargo, P.J. Kleinman, D.K. Arthur, and J.M. McGrath. 2020. FRST: A national soil testing database to improve fertility recommendations. Agricultural \& Environmental Letters 5(1):e20008.

Matson, P.A., W.J. Parton, A.G. Power, and M.J. Swift. 1997. Agricultural intensification and ecosystem properties. Science 277(5325):504-509.

Mausbach, M.J., and A.R. Dedrick. 2004. The length we go-Measuring environmental benefits of conservation practices. Journal of Soil and Water Conservation 59(5):96A-103A.

Mehlich, A. 1984. Mehlich 3 soil test extractant: A modification of Mehlich 2 extractant. Communications in Soil Science and Plant Analysis 15(12):1409-1416.

Miheretu, B.A., and A.A. Yimer. 2018. Spatial variability of selected soil properties in relation to land use and slope position in Gelana sub-watershed, Northern highlands of Ethiopia. Physical Geography 39(3):230-245.

Moebius-Clune, B.N., D.J. Moebius-Clune, B.K. Gugino, O.J. Idowu, R.R. Schindelbeck, A.J. Ristow, H.M. van Es, J.E.Thies, H.A. Shayler, M.B. McBride, K.S.M. Kurtz, D.W. Wolfe, and G.S. Abawi. 2016. Comprehensive Assessment of Soil Health - The Cornell Framework, Edition 3.2. Geneva, NY: Cornell University.

Moges, A., M. Dagnachew, and F. Yimer. 2013. Land use effects on soil quality indicators: A case study of AboWonsho Southern Ethiopia. Applied and Environmental Soil Science 2013. doi.org/10.1155/2013/784989.

Nelson, A.M., D.N. Moriasi, A.M. Fortuna, J.L. Steiner, P.J. Starks, B. Northup, and J. Garbrecht. 2020. Runoff water quantity and quality data from native tallgrass prairie and crop-livestock systems in Oklahoma between 1977 and 1999. Journal of Environmental Quality 49(4):1062-1072.

Northup, B.K., and J.A. Daniel. 2010. Distribution of soil bulk density and organic matter along an elevation gradient in central Oklahoma. Transactions of the ASABE 53(6):1749-1757.

Page, T., P.M. Haygarth, K.J. Beven, A. Joynes, T. Butler, C. Keeler, J. Freer, P.N. Owens, and G.A. Wood. 2005. Spatial variability of soil phosphorus in relation to the topographic index and critical source areas: Sampling for assessing risk to water quality. Journal of Environmental Quality 34(6):2263-2277.

Paul, E.A., H.P. Collins, and S.W. Leavitt. 2001a. Dynamics of resistant soil carbon of Midwestern agricultural soils measured by naturally occurring ${ }^{14} \mathrm{C}$ abundance. Geoderma 104(3-4):239-256.

Paul, E.A., D. Harris, H.P. Collins, U. Schulthess, and G.P. Robertson. 1999. Evolution of $\mathrm{CO}_{2}$ and soil carbon dynamics in biologically managed, row-crop agroecosystems. Applied Soil Ecology 11(1):53-65.

Paul, E.A., S.J. Morris, J.S. Böhm, and R. Lal (Eds.). 2001b.

The determination of soil $\mathrm{C}$ pool sizes and turnover rates: Biophysical fractionation and tracers. In Assessment Methods for Soil Carbon (Advances in Soil Science), 193-206. Boca Raton, FL: CRC Press.

Sanderson, M.A., D. Archer, J. Hendrickson, S. Kronberg, M. Liebig, K. Nichols, M. Schmer, D. Tanaka, and J. Aguilar. 2013. Diversification and ecosystem services for conservation agriculture: Outcomes from pastures and integrated crop-livestock systems. Renewable Agriculture and Food Systems 28(2):129-144.

Schimel, D.S. 1986. Carbon and nitrogen turnover in adjacent grassland and cropland ecosystems. Biogeochemistry 2(4):345-357.

Shiwakoti, S., V.D. Zheljazkov, H.T. Gollany, M. Kleber, and B. Xing. 2019. Micronutrients decline under long-term tillage and nitrogen fertilization. Scientific Reports 9(1):1-9.

Sikora, FJ. 2006. A buffer that mimics the SMP buffer for determining lime requirement of soil. Soil Science Society of America Journal 70:474-486.

Sims, J.T. 1996. Lime requirement. In Methods of Soil Analysis, Part 3. Chemical Methods, ed. D.L. Sparks, 491-515. SSSA Book Series 5. Madison, WI: Soil Science Society of America and American Society of Agronomy.

Singh, B., and D.G. Schulze. 2015. Soil minerals and plant nutrition. Nature Education Knowledge 6(1):1.

Šmilauer, P., and J. Lepš. 2014. Multivariate Analysis of Ecological Data using CANOCO 5. Cambridge, UK: Cambridge University Press.

Soltanpour, P.N., G.W. Johnson, S.M. Workman, J.B. Jones Jr., and R.O. Miller. 1996. Inductively coupled plasma emission spectrometry and inductively coupled plasmamass spectrometry. In Methods of Soil Analysis, Part 3. Chemical Methods, ed. D.L. Sparks, 91-139. SSSA Book Series 5. Madison, WI: Soil Science Society of America and American Society of Agronomy.

Spiegal, S., B.T. Bestelmeyer, D.W. Archer, D.J. Augustine, E.H. Boughton, R.K. Boughton, M.A. Cavigelli, P.E. Clark, J.D. Derner, E.W. Duncan, C.J. Hapeman, R.D. Harmel, P. Heilman, M.A. Holly, D.R. Huggins, K. King, P.J.A. Kleinman, M.A. Liebig, M.A. Locke, G.W. McCarty, N. Millar, S.B. Mirsky, T.B. Moorman, F.B. Pierson, J.R. Rigby, G.P. Robertson, J.L. Steiner, T.C. Strickland, H.M. Swain, B.J. Wienhold, J.D. Wulfhorst, M.A.Yost, and C.L. Walthall. 2018. Evaluating strategies for sustainable intensification of US agriculture through the Long-Term Agroecosystem Research network. Environmental Research Letters 13:034031. https://doi. org/10.1088/1748-9326/aaa779.

Stafford, J.V. 2000. Implementing precision agriculture in the 21st century. Journal of Agricultural Engineering Research 76(3):267-275.
Steiner, J.L., D.D. Briske, D.P. Brown, and C.M. Rottler. 2018. Vulnerability of Southern Plains agriculture to climate change. Climatic Change 146(1-2):201-218.

Stockmann, U., M.A. Adams, J.W. Crawford, D.J. Field, N. Henakaarchchi, M. Jenkins, B. Minasny, A.B. McBratney, V.D.R. De Courcelles, K. Singh, and I. Wheeler. 2013. The knowns, known unknowns and unknowns of sequestration of soil organic carbon. Agriculture, Ecosystems \& Environment 164:80-99.

Takoutsing, B., J.A.R. Martín, J.C. Weber, K. Shepherd, A. Sila, and J. Tondoh. 2017. Landscape approach to assess key soil functional properties in the highlands of Cameroon: Repercussions of spatial relationships for land management interventions. Journal of Geochemical Exploration 178:35-44.

USDA NIFA (National Institute of Food and Agriculture). 2020. Climate Change. https://nifa.usda.gov/topic/ climate-change.

USDA NRCS (Natural Resources Conservation Service). 2019. National soil survey handbook, title 430-VI. Washington, DC: USDA NRCS. http:// www.nrcs.usda.gov/wps/portal/nrcs/detail/soils/ ref/?cid=nrcs142p2_054242.

Van Eerd, L.L., K.A. Congreves, A. Hayes, A. Verhallen, and D.C. Hooker. 2014. Long-term tillage and crop rotation effects on soil quality, organic carbon, and total nitrogen. Canadian Journal of Soil Science 94(3):303-315.

Viaud,V., D.A.Angers, and C.Walter. 2010.Toward landscapescale modeling of soil organic matter dynamics in agroecosystems. Soil Science Society of America Journal 74(6):1847-1860.

Vogel, J.R., G.O. Brown, J. Daniels, W. Phillips, and J.D. Garbrecht. 2000.Watershed management practices (19761999) for the Water Resources and Erosion watersheds at the USDA-ARS Grazinglands Research Laboratory, El Reno, OK. El Reno, OK: USDA Agricultural Research Service Grazinglands Research Laboratory.

Voss, D.A., F. Gray, and M.H. Roozitalab. 1978. Shrink-swell and Other Characteristics of Five Benchmark Soils of Western Oklahoma. Technical Bulletin - Oklahoma Agricultural Experiment Station (USA). No. T-150. Stillwater, OK: Oklahoma Agricultural Experiment Station.

Williams, R.D., L.R. Ahuja, J.W. Naney, J.D. Ross, and B.B. Barnes. 1987. Spatial trends and variability of soil properties and crop yield in a small watershed. Transactions of the ASAE 30(6):1653-1660.

Zhang, S., X. Zhang, T. Huffman, X. Liu, and J.Yang. 2011. Influence of topography and land management on soil nutrients variability in Northeast China. Nutrient Cycling in Agroecosystems 89(3):427-438. 